Euskal ikerketen aldizkaria | Revue d'études basques |

Revista de estudios vascos | Basque studies review

$10 \mid 2005$

Numéro $X$

\title{
Larramendiren euskal liburuak 1745 arte : testu bibliografiaranzko hurbilketa bat
}

\section{Blanca Urgell}

\section{OpenEdition}

\section{Journals}

Édition électronique

URL : http://journals.openedition.org/lapurdum/62

DOI : $10.4000 /$ lapurdum.62

ISSN : 1965-0655

\section{Éditeur}

IKER

Édition imprimée

Date de publication : 31 décembre 2005

Pagination : 247-286

ISBN : 2-86781-409-X

ISSN : 1273-3830

Référence électronique

Blanca Urgell, «Larramendiren euskal liburuak 1745 arte : testu bibliografiaranzko hurbilketa bat », Lapurdum [Linean], 10 | 2005, Sarean emana----an 01 avril 2008, kontsultatu 18 septembre 2020. URL : http://journals.openedition.org/lapurdum/62 ; DOI : https://doi.org/10.4000/lapurdum.62 
Larramendiren euskal liburuak 1745 arte: testu bibliografiaranzko hurbilketa bat

\section{Blanka URGELL}

\section{Aurkezpena}

1. Mitxelenak Historia de la literatura vasca-n azpimarratu zuenez, Larramendik egindako lanen balio nagusien artean bat da berri asko bildu izana argitaratutako obretatik: gogoz bilatu zituen, eta kezka honen ondorioz, euskal literaturaren historiaren lehen zertzeladak eman zizkigun (Mitxelena 1960: 102). Hartakotzat jo zuten, jo ere, ondorengoek, Zabalaren Noticia de las obras bascongadas que han salido a luz después de las que cuenta el P. Larramendi delako opuskuluak (c. 1830) ${ }^{1}$ aditzera ematen duenez. ${ }^{2}$

Ezin esan xx. mendea baino lehenagoko ezein garairi buruz dokumentazioa soberan dugunik. Hala eta guztiz ere, Mitxelenaren adierazpen biribil hark ez du artean lortu inoren jakin-mina piztea, agerian bederen; berdintsu gertatu da Altunak aurkeztu Larramendiren liburutegiarekin (1984), alde batera utzirik Juan Iturriagaren lan bibliografikoa (1992).

2. Larramendiren saio horrek era bateko baino gehiagoko interesak ditu, nondik heltzen diogun. Ardatz biren barnean defini ditzakegu interesok: Larramendigandik liburu zerrendara doan ardatza, batetik, eta Hiztegi Hirukoitza-ren barruko arazoetatik kanpokoetara doana, bestetik.

Nik arloari Larramendiren ikuspegitik heldu diot, eta $H H$ hobeto ezagutzeko asmoz, hiztegi honen euskal iturriak nonbait egotekotan, zerrenda horrexetan egon behar dutelakoan, $H H$-aren euskal lexikoaren iturriak oro aurkitu eta arakatzeko saio zabalago baten barruan (Urgell 2000a).

\footnotetext{
${ }^{1}$ Aipatzen dituen argitaratuen artean, oker ez banago berriena Kardaberatzen Escu Liburua (Tolosa, 1826) da, 24. zenbakiarekin jasoa Zabalaren katalogoan. Noticia Bonapartek argitaratu zuen lehenengoz, Zabala hil eta gero (Donostia, 1856), ohi bezala tirada labur batean (200 ale). Ez dago argitalpen modernorik; Urquijok ale bat eta kopia eskuizkribatu bat zituen bere liburuen artean (Vinson 1891-1898: 282. zb.).

${ }^{2}$ Ziurrenik garrantzi handia izan zuen geroko idazle, irakurle, hiztegigile eta are bibliografoek bertako liburu-eskuizkribuen berri izan zezaten. Etxeberri Sarakoaren eta Landucciren hiztegi eskuizkribatuen berrien transmisioan - Humboldt tartean dela - jokatu zuen paper nagusia antzeman daiteke Urgell (1997: 645-646) lanean. Vinsonek ere erbili zuen, gero ikusiko dugun bezala.
} 
Alabaina, lan hau inprentara eman dut nagusiki uste dudalako baduela interes objektiborik jakiteak Hegoaldeko bat zer irits zitekeen ezagutzera garai haietan euskal literaturari buruz eta, oso bereziki, Iparraldekoari buruz, bi aldeen artean isolamendua egon delako ideiaren aurka. Gogora dezagun hiru bat urtez (1730-1733) Baionan bizi izan zela (gero ikusiko dugu han erdietsi zuela Leizarraga, besteak beste); dena den, badirudi kezka lehenagotik datorkiola (gramatikan jadanik Etxeberri eta Haranburu aipatzen ditu eta; ik. infra $\S 5$ ), eta balirudike geroago ere mantendu zuela harremanik hango norbaitekin, zeren eta atera ahala liburuak jasotzen jarraitu baitzuen hil artean. ${ }^{3}$ Garai hartan berak zeukan ezagutza ohiz kanpokoa bada ere, egia da hiztegiaren arrakastak eta eragin handiak aldeztu bide zutela berak eratutako liburu zerrenda bihurtzea irakurri beharrekoen zerrenda, batetik, eta bestetik, euskaltzaleek — jasoenek bederen- aurrerantzean à la page egoteko Iparraldeko literaturaren ibilbideari beha egotea (cf. Lakarra 1985a: 31-34 eta 1985b; Urgell 1991: 917-919 eta 922-925).

3. Larramendi beti berritzaile gisa aurkeztu izan da. Mitxelenak, 1960an esana gorabehera, honi dagokionez erabateko marra bat ezarri zuen $H H$-aren eta Eranskin-aren artean. Izan ere, honen iturriak - gehientsuenak, behinik behin- erraz identifikatu dira (Mitxelena 1970, Lakarra 1991, etab.; ikus orain Urgell 2001a). Mitxelenak (1961: 364) arazoa ikusi moduan, Larramendik erdal buruhausgarri guztiak itzuli eta gero bakarrik igaroko zen liburuak (Axular, Refranes y Sentencias) eta hiztegiak (Landucci, Harriet) hustera, $H H$-aren gorputza bukatu eta gero, alegia. Beraz, Larramendiren sisteman hau anekdota litzateke, ez legea. Gauzak honela ez direla eta, zehazkiago, egitasmo orokorraren zati ezinutzizko diren gainerako iturri guztiak bezala (etimologia, toponimia, ahozko hizkuntza...), $H H$-aren barruan ere liburuak eta hiztegiak erabili zituela erakustea, hortaz, bada $H H$-aren egileaz dugun irudia goitik behera aldarazteko lain; eta $H H$-az duguna ere, jakina.

\footnotetext{
${ }^{3}$ Cf. Harriet atera berriaz HH-aren hitzaurrean dioena (Larramendi 1745: xxxv). 1745az gero argitaratutako hiru liburu berri aipatzen ditu (Corografía 295-297), eta haietatik bi agertzen dira bere liburutegiko liburuen artean: 1748ko Othoitce eta cantica espiritualac, Zubero herrico batzuk (Altuna 1984: 77, 190. zb.; ik. Vinson 1891-1898: 178, 56b zb.), aipatzen duen zubererazko bakarra, 1749ko Haranederren Philotea (Altuna op. cit. 75, 51. zb.; ik. Vinson op. cit. 195-196, 77a zb.) eta 1750eko Gudu izpirituala (Vinson op. cit. 196-197, 78a zb.). Ez ditu aipatzen, baina bibliotekan egon badaude, Kardaberatzen (ik. Altuna, op. cit. 49, 50, 169, 201, 294), Mendibururen $(i b .178,179)$ eta Peñafloridaren (ib. 285) lanak. Azkena 1764koa dela azpimarra daiteke.
} 
Larramendik hiztegia egiterakoan gehien peitu zuen lagungarria euskal liburu gehiago ez izana dugu; hartaz egiten duen behin eta berrizko aipua da, inondik ere, ezagutu zituen liburu gutxi haiek erabili zituelako seinalerik argiena:

Los libros de una Lengua, siendo muchos y de varias materias, son de un gran socorro en semejantes obras [hiztegietan]. En ellos no sólo se encuentra la copia de voces que se busca, sino también su ortographía, su propriedad, su mejor uso, sus varios sentidos, sus mutuas relaciones: y todo recomendado con la autoridad de sugetos hábiles, que escriben de pensado y con delecto. Mas este socorro me faltó casi enteramente, por ser mui poco lo que se halla escrito en nuestra Lengua, conservada hasta aquí más en la memoria y amor de los Bascongados, que en hojas de papel o en láminas de bronce (1745, eskaintzan).

No tiene el Bascuence libros ningunos impressos ni manuscritos, sino de dos siglos acá. (...). Los pocos libros que he visto impressos en Bascuence, son los siguientes (1745: xxxiv).

No hai libros impressos desta Lengua, sino los pocos que llevo citados... (1745: lii).

Besterik beharko bagenu, baina, hona bere lekukotasuna:

...no pongo ninguna [voz] que, o no aya leído en los libros impressos, u oído en alguno de los dialectos del Bascuence, apuntándolas de antemano con toda prolixidad, para que no se me olvidassen (1745: xlvii).

...he leído con toda reflexión los libros bascongados que llevo citados, apuntando con prolixidad todas las voces bascongadas y sus significaciones, para ponerlas después en el Diccionario (1745: liii).

Akademiaren hiztegi ederra aurrean izaki eta haren bekaitzez beharbada, liburuen autoritateen - laguntzak izan ditzakeen onurak $^{4}$ inoizko argien ageri ziren haren begietan. Larramendi berritzailea izan zela inork uka ezin dezakeen egia borobila da, berak aitortua eta harrotasunez bere gain hartua; haatik, haren adierazpenak irakurrita, malgré lui izan zelako susmoa geratzen zaigu: ez dago esan beharrik bere hizkuntza gaztelaniaren pare jarria eta bere hiztegia ontzeko ibili behar izan zituen bide malkartsuak bestek ireki, zelaitu eta apainduak ikusi nahiago zituzkeela. Egoera oso bestelakoa izanagatik, ostera, hazia ereinda zegoen hiztegigilearen buruan: "los libros de una lengua... son de un gran socorro...”. Ez dago azalpen hoberik hitzaurrean ezagutzen

\footnotetext{
${ }^{4}$ Gai honetan Akademiaren aitzindari eta ereduak, Croscaren hiztegia —nagusiki, Cremonesi-k (1959: 336-339) aldezten duenez-, baina baita honi jarraiki aritu ziren Richelet frantsesa eta Ayala Manrique eta Sobrino espainiarrak izan bide ziren (Lázaro Carreter 1981: 103). Literatur aipamenek garai hartan izan zuten ospeaz, oso adierazgarria da, adibidez, Frantziako Akademiak bide honi uko egin zion arren, frantsesezko hiztegietako haien gorakako erabilerari begirada bat ematea (ik. Quemada 1967: 543-547). Jakina da aspalditik literatura eredutzat hartua izan dela hitzen finkatze, erabilera eta mailakatzeari (jasoa / arrunta) dagokionez (cf., esaterako, Baum 1989: 31). Adibide bat baino ez, alemanerazko hiztegigintza zaharretik hartua: Schottelius-ek (1612-1676) hizkuntzaren emankortasun mugagabekorako aurreikusten zituen muga bakarren artean, liburu onen irakurketa dago (Jones 1991: 140).
} 
dituen apurrez egindako deskribapen (eta sarritan balorapen) zehatzetarako — nahiz, agi denez, ezagutzera emateko gogoak ere hartara bide zuen-, eta ildo beretik doa, ziurrenik, 1745 ondoko euskal literaturari jarri zion arreta, Corografia-ko aipamenak eta bere bibliotekako liburuek erakusten diguten bezala.

Testuen erabileraren aldeko argudio teoriko hauen argitara, eta axaleko miaketa batean bakarrik, orainago haren froga zuzenak erdietsi dira. Zenbait ohar solte baizik ez izan arren, ${ }^{5}$ beren urritasunean arlo honetan zereginik badela egiaztatzea baino gehiago egin dute: $H H$ eta bere iturrien arteko loturak oraindik aurkitu ez baldin badira, bilatu egin ez direlako — eta ez beste ezergatik — izan dela frogatzea, alegia.

4. Lehen urrats modura, Larramendik aipatzen dituen liburuak oro bildu eta erabili zuen argitalpena zein den ebazten saiatu naiz. Axularren Geroko Gero-ak erakutsi digu (Urgell 2001a) iturritasuna baieztatzeko urratsik premiazkoena dela (Urgell 2001a: $\S$ 1.1.18), zeren eta edozein argitalpenek, edo ia, balio bailezake antzekotasunak idorotzeko, baina datu erabakigarriak — huts bateratzaileak, bereziki- erabilitako hartantxe bakarrik egotea izan liteke: jokatzen ari garen iturri kopuru handiarekin esan gabe doa kontu (itxuraz) ñimiño hauen garrantziak goraka egiten duela neurri ikaragarrian. Hau buruan izan arren, halere, sarritan ez da erraza izan, gure testuetako askok bizitza katramilatsua izateaz gainera, Larramendiren datuak ez baitira beti nahi genukeen bezain zehatzak.

Iker arlo hau ez da oso ohikoa euskal filologoen artean; gutxienez Vinson eta Urquijoren lan bikainez geroztik, ezer gutxi aurreratu da argitalpen ezberdinen identifikazio eta aurkikuntzan, eta are gutxiago haien kolazioan. ${ }^{6}$ Halere, esan gabe doa datu bibliografikoak testuen azterketa kritikoaren oinarrizko lagungarri direla (cf. McKerrow 1928 eta Gaskell 1972, besteak beste).

\footnotetext{
${ }^{5}$ Ik. Urgell 1991: 916-917, non hiztegian eta eranskinean jasotzen diren Axularren hitz batzuk eta $H H$-an kausi daitezkeen Leizarraga eta Xurioren beste batzuk iruzkintzen diren. Esan gabe doa Harriet ere hiztegi barruan erabilia izan dela frogatzeak (Lakarra 1991: 255-257, 1993: 270281 eta 1994: 64-67 eta 199) hipotesiaren alde jokatzen duela.

${ }^{6}$ Cf. Blecua 1991: 74: “Hay que decir que, frente a otros países, con otra historia intelectual más normal, ahora se está llevando a cabo [en España] lo que se debería haber hecho ya en el siglo XIX, comenzando por la catalogación de los fondos de las bibliotecas y acabando por la edición de los mismos". Egoera honek berak euskal liburuak ere eragiten dituela ahaztu gabe, pasarteak euskaraz jarrita ezin hobeki deskribatuko bailuke Euskal Herriaren egoera bibliografia eta argitalpenari dagokionez. Katalogatze lanean biziki aurreratu da azken 25 urteetan, Hegoaldean behinik behin, baina esango nuke maiz liburuzainak eta filologoak ez doazela bide beretik, denon kaltetan ziur aski. Filologiaren aldetik ere, salbuespenak egin ahal ditut: Arkotxa (2003, 2004), Atutxa (1999, 2001, 2002), Ruiz Arzalluz (2003) eta Koro Segurola (2001, 2002, 2004), lanbidea berreskuratu (edo sekula erabat galdu ez) delako seinale argi eta bikainak.
} 
Ez daukat nik arlo honetan behar bezalako heziketarik, hurbilketa ortodoxo bat egiteko, baina arloa errespetatzen eta balioztatzen dudanez, espero dut oker ez egotea pentsatzen baitut bildutako datuek balioren bat izan dezaketela, baita agian hortik eratorritako hipotesietako baten batek ere.

5. Zerrenda nagusia Larramendik berak hiztegian "De los libros en Bascuence" atalean (1745: xxxiv-xxxvi) eskaini zigun. Haren balio bibliografikoa gorabehera, iturri idatziak bilatu eta aztertzeko lagungarri bikaina da, Iparraldeko liburuei dagokienez bederen itsuka aritu beharra uxatzen duelako. Hurrenez hurren, honako liburu hauek aipatzen ditu: Laveuxvillen catechima handia eta txikia, Xurio, Beriainen dotrina, Etxeberri Ziburukoaren Noelac eta Manual Devotionezcoa, Exerzizio spiritual batzuk, Argaignaratsen Avisu..., Gasteluzar, Materre, Axular, Harrieten gramatika, BizkaiNafarroa-Gipuzkoetan argitaratutako zenbat dotrina (gehiago zehaztu gabe), Landucci eta Etxeberri Sarakoaren hiztegi eskuizkribatuak eta Leizarragaren Testamentua.

Hauei erantsi behar zaie, Imposible Vencido-ko euskal poesiari buruzko atalak, Etxeberri Ziburukoaren lanekin batera, eskaintzen digun liburu berria: "Fr. Juan de Aramburu, en su librito devocino Escuarra, Mirailla, eta Oracinoteguia" (Larramendi 1729: 379). Garrantzi handikoa izan da, bestalde, Corografia-ko "De los dialectos del Vascuence y del particular de Guipúzcoa" atala (295-302. or.), zeren eta hiztegiaz geroko (eta, beraz, guretzat interes zuzenik gabeko) ${ }^{7}$ argitalpen mordoxka batekin eta lehendik ezagutzen genituen Xurio, Axular eta Beriainekin batera, hiztegian euren izenez ematen ez dituen Hegoaldeko dotrina bi aipatzen baititu: Arzadun eta Elizalde.

Larramendiren idatzietan bildutako berriak bere liburutegiaren edukiaz ditugunekin osatu ditut, atzenik: alde batetik, bere eskuz egin zuen liburu zerrenda (Tellechea-Idigoras 1966a) eta, bestetik, Juan Bautista Landa eskribauak bera hil ondotxoan — josulagunek Loiolatik alde egin eta gero- egindakoa (Altuna 1984, Iturriaga 1992); biak oso baliagarriak izan dira, lehenik Larramendik emandako datuak batzuetan - batez ere eskribauaren zehaztapenez- egiaztatu edota ugaltzeko bidea eman baitidate eta, bigarrenik, hirugarren Hegoaldeko dotrina baten aztarna jasotzen dutelako: Irazustarena, alegia.

\footnotetext{
${ }^{7}$ Baina ez testua datatzeko, agian post quem batzuk eskaintzen ditu eta.
} 


\section{Liburuz liburu}

\section{Leizarraga}

Protestanteen dotrinak baino patu hobexea izan du gure artean Leizarragaren Iesus Christ gure Iaunaren Testamentu Berria-k (Arroxela, 1571), ez bakarrik kanpotik hura sustatu nahi zuten protestanteen eta liburu hartan euskara ezagutzeko bidea aurkitu zuten jakintsu eta jakinahien eraginez, baina baita barrendik, lege zorrotzei aitzi aleak surtatik gorde zituzten ausartei eta, azpiko gatazkari gehiegi begiratu gabe, irakurri eta irakurtzeko gogoa piztu zuten euskaltzale — avant la lettre - apurrei esker ere. ${ }^{8}$ Batzuk eta besteak bilduko lituzkeen zerrenda, egin daitekeen neurrian egin gabe duguna, ezin itxi daiteke Larramendiren izena aipatu gabe.

Lehendik ere zantzu batzuk bagenituen Leizarragaren lana $H H$-aren iturrietako bat izan zela. Haren lexiko bereziak errazten du maiz halabeharrezkoak ezin izan daitezkeen kidetasunak aurkitzea: HH-ko barazbelarra "hortaliza" < baratze belhar (Lç Lc 11, 42), basa-oliboa "acebuche" < ib. (Rom 11, 17), barnadanic "dentro, salir de" < ib. (Mc 8, 12) eta emendiotan, desemendiotan "(a) mejor, a peor" < ceren ezpaitzarete emendiotan biltzen, baina desemendiotan (1 Cor 11, 17) bezalakoak, alegia (Urgell 1991: 916-917). Bestalde, agerian jarri dugu hiztegiko sarrera batean bere izenaz aipatua ageri den euskal liburu bakarra dela (Urgell 1998: 401):

Placa, moneda antigua de España de muy poco valor, creo que es la misma que el Bascuence llamaba pelata, y para significar su poco valor, dezimos pelapat eztu balio, no vale un pito, una pelata, y es locución en que esta voz se nos ha quedado, aunque en el Nuevo Testamento Bascongado se pone por moneda de poco precio.

Gure lanaren lagungarri, bestetan ez ditugun kanpoko xehetasunak aurkez daitezke, Larramendik eskuztatu zuen alea nolakoa zen eta, beraz, Leizarraga zenbateraino ezagutu zuen finkatzerakoan. ${ }^{9}$

\footnotetext{
8 Leizarragaren iraupenaren inguruko datu gehienak han-hemen sakabanatuta daude. Fontainebleuko ediktuaren (1685) ondorioetako bat —arinenetakoa, bestalde - protestanteen idatziak suntsitzea izan zen (ik. Olaizola 1993: 254). Urkizuk (1989: 53) kaputxinoen Baionako eta Olorongo komentuetan ziren Leizarragaren ale desagertuez mintzo da, adibidez, baina zenbat horrelako? Pentsatzekoa da Europan zehar (Espainiatik Holandaraino eta Ingalaterratik Italiaraino) barreiatuta dauden aleak ihesi abiatu zirenek atereak izan zirela maiz (Olaizolak, $i b$. 184, Vinsonek eta Dodgsonek haien kokapenaz emandako berriak laburbiltzen ditu). Europako hizkuntzalari eta hizkuntzazaleek Leizarragaren lanaz egin zuten erabilerari buruz, ik. Urkizu 1986 eta 1989: 53-66. Bestalde, Testamentuaren geroko itzultzaileek — Haraneder, Harriet eta Duvoisin, bederen — denek erabili zuten (Ruiz Arzalluz 1987), baita 1828ko Testament Berria-ren itzultzaileak ere (Schuchardt 1900: 134).

${ }^{9}$ Ez nuke saihestu nahi Leizarragaren aleen arteko ezberdintasunaren auzia (Schuchardt 1900: 134, Lacombe 1907, Dodgson 1907, Vinson 1907, Lafon 1944: 49 eta, labur bilduz, Zulaika 1999: 39-40). Gai honek mende hasieratik hona pairatu duen isiltasuna dela eta (aipamen labur bat
} 


\subsection{Larramendiren alea}

Larramendiren paperen artean Leizarragaren Testamentuaren zati baten kopia eskuizkribatua gordetzen da (Mt 25, 26 arte). Honi berak bere eskuz ezarri zion oharrari esker (Tellechea-Idigoras 1966b: 175-176), badakigu Gaztanbide izeneko Baionako kanonigo baten alea luzaro esku artean izan zuela. Baionatik Loiolara zenean (1734) aldean eraman zuen eta kopiatzen hasi baina, halako batean, Gaztanbidek eskatu, eta lana bukatu gabe itzuli behar izan zion. Ezagunegia ez bide den ohar hori kopiatuko dut hurren Tellechea-Idigorasen argitalpenetik: ${ }^{10}$

Esta copia del Nuevo Testamento la empecé con ánimo de llevarla hasta el cabo, por ser una pieza mui rara y que ya apenas se encuentra. Tuve algunos años en mi poder el Testamento Nuevo en bascuence, impreso, de que doi cuenta por extenso en el Prólogo del Diccionario. Era su dueño Mr. de Gaztambide, canónigo de Baiona, a quien se lo saqué por medio de un su amigo, para algún tiempo. Y como vi que no se acordaba de pedírselo, vine con él a Loiola y comencé a copiarlo, pensando tener tiempo para acabarlo.

Pero acordóse, en fin, el canónigo de su libro y se lo pidió a su amigo y éste a mí, con tanta prisa y rigor, que diciéndole que le havía empezado a copiar, no quiso darme tiempo para acabarlo, y se lo volví. Y quedáronme estos cartapacios que llegan hasta el Cap. 25 del Evangelio de S. Matheo y su vers. 26. Y aunque sea así, es pieza digna de guardarse en la Librería o en otro paraje seguro. Para inteligencia de su dialecto, léase lo que tengo dicho en el otro Prólogo del Diccionario.

Loiola maio 5 de 1761

Berria ez da nolanahikoa: Leizarraga hiztegirako gaiak biltzen zebilen garaian eduki zuen, Baionako egotaldian lortua, ziurrenik gainerako Iparraldeko liburu gehienak bezala, ${ }^{11}$ Vinsonek zioenez (1891-1898: 19, 3a zb.). Dena dela, Testamentuaren aurkikuntza ez zen ustekabekoa izan; honela kontatzen digu $H H$-aren hitzaurrean eskaini zion atalean —-"Del Nuevo Testamento en Bascuence" (1745: xxxvi-xxxviii)— aurkitzaileak berak:

Don Nicolás Antonio dixo en su Bibliotheca Española aver visto el Nuevo Testamento en Bascuence en Roma en la Librería del Cardenal Barberino. He oído hablar a muchos de Biblia Bascongada, y que la han visto en Roma éstos y los

aurki daiteke Olaizola 1993: 183-184n), ez da hemen ezer berririk idoroko baina, edozein modutan, aukera baliatu nahi nuke ikerbidea zabalik dagoela gogoratzeko.

${ }^{10}$ Argitaratzailearen oharrak hauxe dio: "Fajo en $8^{\circ}$, a lápiz letra D. Dice El Testamento nuevo en Bascuenze empezado. Obras del P. Larramendi. Siguen 50 fol. con la traducción vasca copiada Iesus Christen Evangelio Saindua S. Matheren araura. Todo ello se encuentra en la Real Academia de la Historia, Jesuítas, leg. 62".

11 Baina ez denak: Imposible Vencido-ren garaian Etxeberriren Manual-a eta Noelak eta Haranbururen Miraila behinik behin ezagutzen zituen, gorago esan bezala. 
otros; pero es cierto que no ay más que el Nuevo Testamento que cita Don Nicolás Antonio. Después de muchos años de solicitud y diligencia, le he avido a las manos; y porque es pieza rara, quiero dar della alguna mayor noticia en gracia de los curiosos (Larramendi 1745: xxxvi). ${ }^{12}$

Hitz hauen ostean aurkitzen dugu, hain zuzen, kopiaren oharrean aipatu zuen alearen deskribapena, guretzat ezinutzizkoa, testuaren nondik norakoak xehe-xehe agertzen baititu, inolako zalantzarik gabe oraindik begi aurrean zuela. ${ }^{13}$ Ikus ditzagun, bada, Larramendik eskainitako zehaztasunak:

1) Izenburua, etab. dakarren orrialdea eta eskaintza falta zitzaizkion, baina eskuz osatuta zeuden. Izenburuan erreginaren ezkutua zegoen, eta Larramendik ematen duen ezkutu azpiko leienda ongi jasota dago, grafiazko aldaketa zenbait gorabehera:

Haur da ene Seme maitea, ceinetan neure atseguin ona hartzen baitut, huni beha çaquizquiote (Leiz.).

Haur da ene seme maitea, ceinetan neure atseguin ona hartzen baitut, huni beazaquizquiote (Lar.).

Halaber, leku beretik "Está impresso en la Rochela según el M.S. año de 1571, en la Imprenta de Pierre Hautin" ateratzen du; cf. jatorrizkoa:

Rochellan.

Pierre Hautin, Imprimaçale. 1571.

Eskaintzak, biak gordetzen zituen aleak, frantsesezkoa eta euskarazkoa; hona hemen Leizarragaren eta Larramendiren bertsioak, elkarren parean jarrita:

Leizarraga

A TRESILLUSTRE Dame Ieanne d'Albret, Roine de Nauarre, Dame souueraine de Bearn, \&c. son treshumble \& tresobeissant seruiteur Iean de Liçarrague de Briscous desire grace \& paix en Iesus Christ.

\section{Larramendi}

à très-Illustre Dame Jeanne
d'Albret, Reine de Navarre,
Dame Souveraine du Bearn, \&c.
son très-humble, \& très-
obéissant Serviteur Jean de
Lizarraga de Briscous, désire
grace, \& paix en Jesus-Christ.

\footnotetext{
${ }^{12}$ Testamentuaren alea 1730-1733 bitartean lortu zuenez gero, berekin zeukan Mayansen liburua ezagutzerako; halaz ere, hitzaurreko pasartea idazterakoan baliteke haren berriak ere kontuan izatea; Nicolás Antonioren aipua behintzat (Landuccirena bezalaxe) hari zor diola dirudi; erka bitez Larramendiren hitzak haren Orígenes-ekoekin (1737: 350): “...aviendo sido, si no me engaño, el primero i casi único libro que se ha impresso en ella [euskaraz] la Traducción del Testamento Nuevo, que salió a luz año MDLXXII i atestigua don Nicolás Antonio que estava en la librería del cardenal Francisco Barberino".

${ }^{13}$ Zehaztasunak berak horixe adierazten du, baina gainera, ohar bedi hurren aipatzen dituen adibideak ez direla denak Mateorenak: beraz, nabarmena da hitzaurrea idatzi orduko (c. 1742) oraindik alea gordetzen zuela nabarmena da. Honek iradokitzen du $H H$ ontzerakoan osoki hustu ahal izan zuela, bestela ere egiazta daitekeen bezala (Urgell 2000a: § 9.2.8.4).
} 
Gucizco Andre noble Ioanna Albrete Naffarroaco Reguina Bearnoco Andre guehién \&c., denari, bere cerbitzari gucizco chipiac eta gucizco obedientac, Ioanne Leiçarraga Berascoizcoac, Iesus Christen gratiá eta baquea desiratzen.
Gucizco André Noble Joana Albreta Nafarroaco Erreguina, Bearneco André guehien denari, bere servitzari gucizco chipiac, eta gucizco obedientac, Joanes Lizarraga Berascoiscoac JesusChristen gracia, eta baquea desiratzen.

2) Testamentua osorik zegoen: "Los quatro Evangelios. Los Actos de los Apostoles. Las catorce Epistolas de San Pablo. La Epistola Canónica de Santiago, Las dos Epistolas de San Pedro. Las tres de San Juan. La Epistola Canónica de San Judas. Y el Apocalipsis de San Joan" (ibid.).

3) "y al fin pone los nombres proprios del Hebreo y Griego, que se hallan en el Nuevo Testamento, y su significación en Bascuence" (ibid.). Hots, Apokalipsiaren ondo-ondoan datorren "TESTAMENTV BERRIAN diraden icen propri Hebraico eta Greco batzuén declarationea"; adibide gisa, zerrendako 1, 3 eta 4. sarrerak eransten ditu:

\section{Larramendi}

Aaron, mendia.

Abraham, anitzen aita.

Adam, guizonà, edó lurrezcoa, edo canabera.

\section{Leizarraga}

Aaron, mendia, edo mendico guiçona. Abraham, anhitzen aita.

Adam, guiçona, edo lurrezcoa, edo canaberá.

Ez ditu gauza zenbait aipatzen eta, hain deskribapen zehatzaren ondoren, pentsatzekoa da egon ere ez zeudela:

"BATBEDERAC IAQVITECO, eta maiz iracurtzeco duen Aduertimendua nola Iesus Christ den Iaincoaren Leguearen fina, eta gure saluatzeco moien bakoitza", 19 orrialdetakoa, Testamentuaren testuaren aurrekoa. Egingo nuke alea nahita moztua izan zela, atal hau dela kausa hain zuzen, dotrina heretikoak zeuzkakeelakoan, eta muina — Testamentua euskaraz- salbatu nahirik.

"TESTAMENTV ÇAHARRAC eta berriac iracasten draucuten guciaren sommarioa", 6 or., hau ere Testamentu aurrekoa, lehengoarekin batera erauzia, antza denez.

"TESTAMENTV BERRICO hitz eta minçatzeco manera difficil bakoitz batzu bere declarationéquin", aipatu izen-hiztegiaren ostean. 13 or.

"ÇUBEROACO HERRIAN usançatan eztiraden hitz bakoitz batzu hango ançora itzuliac", aurrekoaren ondoren; ez da orrialde eta erdira iristen.

"TESTAMENTU BERRICO materien erideiteco Taulá", aurrekoaren ondoren; 48 or.

Vinsonek (1891-1898: 6, 3a zb.) diosku Leizarragaren ale batzuek bukaeran dotrina, Erregeari aldarrikapena eta fedezko aitorpena daukatela. Ez dirudi, esanak esan, antzekorik zegoenik gurean, Larramendik ezagutu orduko, behinik behin. Eta, 
amaitzeko, bistan da Larramendik ez zuela beste liburuaren (Kalendrera eta $A B C$ batzen dituenaren $)^{14}$ inolako berririk izan.

\subsection{Leizarraga HH-ko hitzaurrean}

Gainerakoei lerro apur batzuk eskaini zizkien bitartean honako honi atal oso bat egin baitzion, "porque es pieza rara". Testamentua itzulita izatea - hainbat literatur hizkuntzaren oinarri- ${ }^{15}$ asko izan behar zen josulagun euskaltzale batentzat baina, gainera, argi dago bere hitzetan, liburuaren hizkuntzazko aberastasunek eurek ere erakarri zutela.

Hasteko, egon zitezkeen erreparoak uxatzeko, edo ematzeko bederen, aldarrikatzen $\mathrm{du}^{16}$ egilea kalbindarra izan arren itzulpena zuzena dela, —orduan ez zen huskeria, dakigunez: ${ }^{17}$

Por lo demás, no se puede conocer que sea calvinista el traductor, que está a mi entender muy ajustado en su traducción (1745: xxxvii).

Mateoren Testamentuaren lehen atalaren aurkibidea ere eskaintzen du, antza denez Vulgataren munduan bizi zirenentzat honelakoak ezezagunak ziren eta:

Larramendi

Jesus-Christen Evangelio Saindua S. Matheuen araurá.
Leizarraga

\section{IESVS CHRISTEN EVANGELIO SAINDVA S. MATHEVEN}

\footnotetext{
${ }^{14}$ Vinsonek dioenez (1891-1898: 43, 4. zb.), honen aleak Testamentu Berriarenak baino amorru handiagoaz txikituak izan bide ziren Luis XIII.aren garaiko kontrakarrean.

${ }^{15}$ Ezagutzen dudan honi buruzko azken oharra, gure artean, Ruiz Arzalluzena (1987: 709) da; bertan aurki daitezke oinarri-oinarrizko bibliografi erreferentzia zenbait.

${ }^{16}$ Oso bestelako iritzikoa izan genuen Haraneder, zeinak bere itzulpen eskuizkribatuaren Aitcin-Solhas-ean, Leizarraga "guiçon etsai eta dohacabe" eta "Calviñen (...) heresia poçoatuaz cutsatua" dela dioen - Ruiz Arzalluzek (1987: 712) begi zoliaz bakandutako hitz berberak errepikatuta-, hurren bere itzulpenerako erabiltzen duen arren, filologo berak (ib. 716-717) frogatu bezala. Zer ez ote zuten jaulkiko Larramendiren mihi-luma azkarrek, pasarte hau irakurtzerik izan balu, Corografía-n (297. or.) Haranederri eskaini zion aipamen ez oso aldekoaren ordez?

17 Pio IV. aita sainduak, Trentoko Batzarra bukatu eta berehala, "Liburu debekatuen zerrendaren" arauak jasotzen zituen bulda bat atera zuen; laugarren arauak honela zioen: "Eskarmentua hartu dugu, hizkuntza arruntaz itzulitako Biblia zilegi izatetik on baino gaitz gehiago datorrela, giza ahultasuna dela kausa. Arlo honetan apezpikuaren eta inkisidorearen iritzia begiratu behar da; apaizari edo aitortzaileari galdetuta, eurek eman dezakete egile katolikoek itzulitako Biblia irakurtzeko baimena, baldin uste badute halako irakurketatik ez dela kalterik etorriko, sinismenaren eta pietatearen hazkuntza baizik..." (ap. Buzzetti 1986: 97-98; itzulpena eta etzanak nireak dira). Buzzettiren liburuaren itzultzaileak (98. or., 9. oh.) arau hau Espainiako Inkisizioaren Zerrendaren 5.a izan zela diosku, baina argi eta gogorragoa Erromakoa baino.
} 
1. Jesus-Christen burhaso, eta araguiaren arauezco aitzinecoac.

18. Nola hura Spiritu Sainduaganic concebituric, Maria Virgina Josephen emazteaganic jayo izan den.

20. Cergatic icen eman zayon Jesus.

23. Eta Emmanuel.
ARAVRA.

1. Iesus Christen burhasso eta haraguiaren arauezco aitzinecoac.

18. Nola hura Spiritu sainduaganic concebituric, Maria virgina Iosephen emazteaganic iayo içan den.

21. Cergatic icen eman çayón Iesus.

23. Emmanuel.

Formazko ezaugarri honetaz gainera bada deigarria iruditu zitzaion beste bat: are ertzetako oharrak ere euskaraz itzulita egotea, alegia.

Gainerantzean, batez ere hizkuntz berezitasunez mintzo da, agerian jarriz lanbide honetan begi zorrotzak zituela eta, gainera, euskalkien arteko ezberdintasunez asko zekiela; honako ezaugarri hauek banan-banan aipatzen ditu:

1) Bai Kristok Apostolu eta gainerakoei, bai Apostoluek Kristori hika hitz egiten diete. Asaldatu gabe esaten du, ez alde ez kontra agerturik, eta ondoko pasarteak adibide gisa aipatzen:

\section{Larramendi}

erraguc, noiz gauza hauc izanen dirade? (Math. 24).

hi aiz Juduen Reguea? (...) hic dioc (Math. 27).

cergatic negarrez ago? noren billa abil? harc ustez ecen baratze-zaina cela diotsa, Jauna, hic eraman baduc hura, erradac, non ezarri duan, eta nic quenduren diat (Joan. 29 [sic]).

2) ukan izan-en ordez sarritan agertzen da: hau itzultzailearen euskalkiari (BN-ari) egozten dio, eta Nafarroa Garaian ere aurkitzen den berezitasuna dela erantsi.

3) Geroaldian -(r)en marka aurkitzen du, behin ere ez - ko edo -go. Bide batez, -en / -ren banaketa zehazten du, azkena bokalez amaitzen diren aditzetan (arturen, ecarriren) agertzen dela esanez. Areago, geroaldi mota hau Lapurdin eta Nafarroan ere baliatzen dela diosku, baina hauetan aditz bakan batzuetan (emanen, izanen) bakarrik gauzatzen dela, gainerakoetan -ko (artuco, ecarrico) erabiltzen duten bitartean. Honako hau da adibide modura dakarren pasartea:

\section{Leizarraga}

Erraguc, noiz gauça hauc içanen dirade? (Mt 24, 3).

Hi aiz Iuduén Reguea? Iesusec erran cieçón, Hic dioc (Mt 27, 11).

...cergatic nigarrez ago? noren bilha abila? Harc ustez ecen baratze-çaina cela, diotsa, Iauna, baldin hic eraman baduc hura, erradac non eçarri duán: eta nic kenduren diat (Io 20, 15). 
ecen duen guciari emanen zayo, eta ambat gueyago uca[n]en du; baina deus eztuenari, duena ere edequiren zayo (Math. 25, 29).
Ecen duen guciari emanen çayó, eta hambat guehiago vkanen du: baina deus eztuenari, duena-ere edequiren çayó (Mt 25, 29).

4) Subjuntiboa indikatibozko iraganaldi burutuaren ordez erabilia dago (alegia, "aoristo" deitu ohi duguna): adibidez, icusi cituen-en ordez icusi citzan; deitu zuen-en ordez, deitu cezan; igan edo igo zan-en ordez, igan cedin, etab.

5) $r$-z hasten diren maileguak halaxe idatzita dauden arren (rendatu, recibitu, reguea), ahoskapena err- dela ulertzen du Larramendik, "porque no ay voz en nuestra lengua que empiece con $r$ ". Bestetan (hitz erdian eta bukaeran) ohi baino $r$ bikoitz gehiago aurkitzen ditu, ordea. ${ }^{18}$

6) Gramatikazko atalari bukaera emateko "diestríssimo bascongado" deitzen dio, hikaren erabilera zehatza _-"assí en los verbos regulares como en los irregulares", hots, hala aditz perifrastiko nola trinkoetan— goraipatuaz eta ondoko lerrokada luzea erakusgarri modura kopiatuaz:

enzún ucán duzue ecen errán izán déla, on eritziren ${ }^{19}$ dráucac euré hurcoarí, eta gaitz eritziren dráucac euré etsayarí. Bainá nic erráiten dráuzuet, onhets itzázue zuen etsayac, benedicá itzázue maradicátzen zaitúztenac, ongui eguiézue gaitz daritzúenei, eta othóitz eguizue oldártzen zaizquitzúenacgatic, eta persecutátzen zaitúztenacgatic, zuen aità céruetan dénaren haour záretentzat... Ecén baldin zuei on daritzúenei on badariztezue, cer sari ucanen duzue? (Math. 5, 43 t. hur.).
Ençun vkan duçue ecen erran içan dela, On eritziren draucac eure hurcoari, eta gaitz eritziren draucac eure etsayari.

Baina nic erraiten drauçuet, Onhets itzaçue çuen etsayac, benedicaitzaçue maradicatzen çaituztenac, vngui eguieçue gaitz daritzuëney: eta othoitz eguiçue oldartzen çaizquiçuenacgatic, eta persecutatzen çaituztenacgatic.

Çuen Aita ceruëtan denaren haour çaretençat: (...).

Ecen baldin çuey on daritzueney on badarizteçue, cer sari vkanen duçue? (Mt 5, 43-46).

Bereiz aipatzekoak dira, berriz, Leizarragaren hitzei hitzaurrean zehar egin zizkien bi aipamenek, beti ere garatzen ari den teoria zabalagoen adibidetzat emanak.

\footnotetext{
${ }^{18}$ Adibiderik ematen ez duenez gero, asmatu egin beharko genuke zeri dagokion, baina egia esan, ez dakit zer den: Schuchardtek (1900: 177) <r>-ren ordez dauden <rr> batzuk seinalatu zituen (batetarra 'batetara', error 'eror', erroriren 'eroriren', eurrorrec 'eurorrek', itsassorraco 'itsasorako', lekorrerat 'lekorerat') eta, hauetaz gainera, fierretaco, non $r r$ ahoskatu egiten zen. Ez dirudi, ostera, hain errata nabarmenek Larramendiren iruzkina eragin zezaketenik. Gainerantzean, Leizarragak -r\# / -rrB banaketa fidelki gorde ohi du, dakidalarik.

${ }^{19}$ Jat. oritziren.
} 
Leizarragak latinezko hitz bat beti berdin itzultzen ez duela frogatzeko, lat. corpus testuinguru berean agertzen deneko bi pasarteok dakartza:

ecen non ere izánen baitá sarrasquia, hará bilduren dirade arranoac ere (Math 24, 28).

non ere izánen baitá gorputza, hará bilduren dirade arranoac ere (Lc [gehiago gabe]).
Ecen non-ere içanen baita sarrasquia, hara bilduren dirade arranoac-ere $(\mathrm{Mt}$ 24, 28).

Non-ere içanen baita gorputza, hara bilduren dirade arranoac-ere (Lc 17, $37)$.

Honen haritik, sarraski hitzaz zekien guztia —ez soilik Leizarragagan ikasiabiltzen du, eta ez da gutxi: ohartu liburuetako eta herrietako lekukotasun bildumari:

En el primer lugar [Mt 24, 28] sarrasquia esta puesto en el sentido de cadáver, y es la voz que ponen muchos Intérpretes, y Santos, y aun la Escritura misma en Job, a cuyo lugar se hace alusión; porque a él se arrojan las águilas como a presa suya, que arrebatan, y en que se acaban. La voz sarrasquia, de que usan también Argaignarats y Gazteluzar, ${ }^{20}$ y es muy corriente en Oyarzun y otros Lugares, significa qualquiera cosa que se quisiere arrebatar, y qualquiera que se dexa ò arroja entre muchos, para que la arrebaten: y esto es lo que quadra bien al cadáver respeto de las águilas y otras aves de rapiña (Larramendi 1745: xxxviii).

Hiztegian, bidenabar, bi adierak jasota daude:

Arrebatiña, lo que se arroja ò dà à muchos, para que lo arrebaten, sarrasquia.

Cuerpo muerto, illotzá, sarrasquia.

Bigarren aipamena askoz garrantzitsuagoa da euskal lexikoaren historiarako, Leizarraga eratorbide baten adibide eta eredutzat hartzen baitu, -kide, -kida, -kidatu-ren erabilera zuritzeko (cf. Urgell 2000a: § 2.1.5), hain zuzen:

Por esto tambien en el Nuevo Testamento se dice servitzariquidea al consiervo (1745: 1)

Eta, jakina, hiztegi barruan ere badago:

Consiervo, servitzariquidea.

\subsection{Leizarraga letraldatzen}

Aurkezpen hau gauzatzeko Larramendik Leizarragaren testutik kopiatutako zenbait pasarte labur ekarri ditut eta jatorrizkoekin erkatu. Adierazi bezala, funtsean fidela izanik ere, baditu aldaketa txiki batzuk. Eranskin-eko joerak kontuan izanik, pentsa dezakegu aldaketok erakuts diezaguketela hiztegian nola tratatu zuen. Eta, izan ere,

\footnotetext{
${ }^{20}$ Erraz ediren dezakegu orain Gasteluzarren adibiderik: Haren odol sarraskiak / eta tromenta handiak jasanen tut gogotik (Gç 135, ap. OEH, s.v. sarraski 3). Argaignaratsek (beti OEH-aren arabera, jakina) ez du hitz honen adibiderik Devoten Breviarioa-n (1665); beraz, bazukeen galdutzat jotzen dugun Avisu-n (1641; ik. infra § 6).
} 
gehienak ohiko grafi egokitzapenak (Urgell 2001a: II, § 1.1) —gehi formaren hegoalderatze ttikiren bat (ib. II, $\S 1.1 .17$ ) - dira eta, Eranskin-ean bezalaxe, ez sistematikoak:

- $<c ̧>\rightarrow<\mathrm{z}>$ : guiçona $>$ guizona, içan $>$ izan, çayon $>$ zayon, gauça $>$ gauza, etab.

- $<\mathrm{k}>\rightarrow<\mathrm{c}>$, $<\mathrm{qu}>$ : kenduren $>$ quenduren, ukan $>$ ucan.

- Hitz hasierako eta bokal aurreko $<\mathrm{i}>,<\mathrm{I}>\rightarrow<\mathrm{j}>,<\mathrm{J}>$ : Ioanna $>$ Joana, Ioannes $>$ Joanes, Iesus $>$ Jesus, Iosephen $>$ Josephen, iayo $>$ jayo, Iuduen $>$ Juduen, etab.

- $<\mathrm{h}>$ kendu: haraguiaren $>$ araguiaren, hambat $>$ ambat, baina hauc, hurcoari, haour, hara, etab. Baita ozen ondoan ere: anhitzen $>$ anitzen, bilha $>$ billa. Halere, badu hasperenen adibiderik oraindik: onhets, othoitz.

- $\langle\mathrm{v}>$ etimologikoa maileguetan: cerbitzari $>$ servitzari.

- Grafia bikoitzak bakundu: Ioanna > Joana, Ioannes > Joanes, Naffarroaco > Nafarroaco, burhasso $>$ burhaso.

- $<\mathrm{ti}>$ etimologikoa $\rightarrow<\mathrm{ci}>$ : gratia $>$ gracia .

- Hitz hasierako $r>$ err (cf. gorago esana): Reguina $>$ Erreguina baina Reguea.

- Txistukariaren "zuzenketa": cerbitzari > serbitzari.

- $<\mathrm{z}>\rightarrow<\mathrm{s}>/-\mathrm{C}$ : Berascoizcoac $>$ Berascoiscoac.

- $<\mathrm{y}>\rightarrow<\mathrm{i}>/ \mathrm{V}-\#$ : daritzueney $>$ daritzuenei, çuey $>$ zuei.

- $<$ nç $>\rightarrow<$ ntz $>$ : çaretençat $>$ zaretentzat, baina ençun $>$ enzun.

- $<\mathrm{hi}>\rightarrow<\mathrm{y}>/ \mathrm{V}-\mathrm{V}$ : guehiago $>$ gueyago, baina guehien .

- Aditz nagusia eta laguntzailea bereizi: benedicaitzaçue > benedicá itzázue.

- Aldaketa batzuek Leizarragaren hizkuntza mendebalderagoko ezaugarriez janzten dute: nigarrez $>$ negarrez, abila $>$ abil, vngui > ongui, çaizquiçuenacgatic > zaizquitzuenacgatic.

- Bestetan, berak hobeto ezagut zezakeen formaren alde egin duela dirudi (berariaz izan den, ala ez, hori ez dakigu): Bearnoco $>$ Bearneco.

\section{Axular}

Ezagutu zuenetik, Larramendirentzat euskal idazleen eredu bilakatu zen; ${ }^{21}$ hona hemen euskal liburuen zerrendan egiten dion ohorezko aipamena:

Síguese un tomo en octavo del célebre Don Pedro de Axular, rector de Sara, cuyo título es Guerocó guero, y su asunto de non procrastinanda Paenitentia, y tiene 60 capítulos. El bascuence es elegante, proprio, puro, abundantísimo, el asunto tratado por principios, probado por la Sagrada Escritura, Padres de la Iglesia, exemplos y semejanzas muy oportunas. Los vicios pintados al natural, y convenientísimos sus remedios. Anda en manos de muchos, y debiera en las de todos los bascongados: y oxalá hubiera dado a luz la segunda parte que ofrece al principio al lector. Está impreso en Bourdeaux, año 1642, como consta de las aprobaciones y licencias (Larramendi 1745: xxxv).

Are euskaldun on eta txarrak —zehatzago, euskaraz letradun eta gabeakbereizteko neurri gisa ezarri zuen beste pasarte batean:

${ }^{21}$ Gai honetaz, oro har, ik. Urgell 1991. 
...sin trabajo ni aplicación, y sin una onza de talento en estas materias, de repente se levanten en críticos de todo esto unos Bascongados ignorantes, que no saben Latín, que hablan mal Romance y peor su Bascuence. Pónganse a escrivir una carta en su Lengua, no aciertan; abran a Axular para leerlo, se atascan; léanlo, y les parece Griego (ib. xlvii).

Horregatik inor ez bide zen harritu Eranskin-aren iturrietatik bat, iturririk garrantzizkoena, izan zela egiaztatu zenean, baina axolakabekeriaz edo bestela, bertako aurkezpenean "he repasado con mucho cuidado..." Larramendiren esanari eta haren ondorio nabarmenei ez ikusiarena egin izan zaie. Axularrengandiko hitzetan Eranskinaren eta $\mathrm{HH}$-aren artean aurkitu ditugun batetortze ugariak (Urgell 2001a: II, § 1.6) ziurrenik izozmendiaren tontorra baino ez dira.

\subsection{Larramendiren alea}

Hiztegiaren hitzaurrean emandako datuetan oinarrituta, Vinsonek (1891-1898: 87, $22 \mathrm{~b} z$ b.) erabaki zuen bigarren argitalpena Larramendik lehenengotzat hartu zuela. Ez da oso zaila frogatzen, bestalde, GGero argitalpen narrasaren erabilerak eragin dituen hutsak badirela $H H$-an; adibidez, ${ }^{*}$ cheitu eta familia:

GGero 215 cheiten vs Gero ib. ehaiten > HH "Tejer, eó, eotu, eaitu, cheitu". "Tejedor, eulea, eaillea, cheilea".

Larramendi, dirudienez, GGero-aren bi ale biltzera iritsi zen: "Axular, duplicado Gueroco-guero" dio bere eskuz osatu zuen zerrendan (Tellechea-Idigoras 1966a: 356, 70. zb.); ezbairik gabe, hiltzerakoan utzi zituen liburuetatik erakargarriena izan zen, zeren eta denbora laburrik artean Landa eskribauak egin zuen zerrendan ez baitago haren arrastorik ere: Altunak (1984: 71) iradoki bezala, haietako bat katalogo berean Kardaberatzen gelan aurkitzen dugu, ziurrenik.

Esan gabe doa azterketarako GGero honen ale bat baliatu dudala. ${ }^{22}$ Ziur aski aldi berean Gero-arekin ere jokatzea —Eranskin-ean egin bezalaxe- oso aberasgarria izango litzateke, bi argitalpenen arteko gorabeheren munduan aurrerapausoak egiteko parada emango bailiguke, baina antzeman ditudan zailtasun handiek ahalik errazenera jotzera eraman naute, xedea begi-bistatik galaraz diezaguketen kontuetan sartu gabe. ${ }^{23}$

22 Gasteizko Filologi Fakultatean gordetzen den mikrofilma, Eusko Legebiltzarraren Liburutegiko alearen kopia (Amezaga 1983: 65. zb.), alegia.

${ }^{23}$ Axularren argitalpenen kontua aztertzeke dago. Lehen eta bigarrenaren arteko kolazioa bukatuta badut ere, beldur naiz ondorioak ez direla erabatekoak izango Euskaltzaindiak argitara duen faksimileaz bestelako alerik ikusteko parada hartzen ez dudan bitartean. Izan ere, argitalpen honetan eskuz egindako hainbat zuzenketa eta eransketa aurkitzen dira, ertzetan eta 


\subsection{Axular transkribatzen}

Axular bere eskuetatik igaro ondoren nola gera zitekeen —eta, beraz, hiztegian nola edo nolatsu barneratu zukeen- ezagutzeko parada eman zigun Corografía-n, lapurteraren erakusgarritzat haren pasarte labur bat aukeratu zuenean:

Larramendi (Corografia 297-298)

Bada chinhaurriaren gobernuaz zuhurtziaz, hornizoinaz, eta biltzen duen mantenuaz, norc cer erranen du? Norc eztu miretsico, ta gogoeta eguinen? Spiritu Sainduac berac igortzen gaitu animalia ttipitto onen gana, cer eguin behar dugun icastera, erraiten duela: Vade ad formicam, etc. Zoaz, naguia, chinhaurriagana, eta considera itzatzu haren bideac eta bidescac, joan-etorriac eta itzul-inguruac, nequeac eta trabailluac, eta icasico duzu zuc ere nola bear duzun aitzinerat eta betiere bici, ibili eta gobernatu. Harc eracusleric eta guidariric gabe, berac bere buruz biltcen du udan, neguaren iragaiteco bear duen mantenua, bazca eta bihia. Eta bihi hura gordetzen du lurrean barrena, berac eguinicaco gambaraetan, eta bihiteguietan. Eta hain da zuhur eta goithatu, ecen campoan ecin deus izanez, bere bilduetara, bildu bear duenean, lehenic hozitu bear duen burutic hasten batzaica bihiari: ceren bercela sor liteque bihi hura, buztan liteque, be[1]ar bihur liteque: eta guero handic harat, alfer-lan guertha lequidicaio, bere leheneco zuhurtzia gucia.
Axular (GGero 36-37)

Bada chinhaurriaren gouernuaz çuhurtciaz, (...) horniçoiñaz, eta viltcen duen mantenuaz, norc cer erranendu? Norc eztu miretsico, etagogoeta eguinen? Spiritu Sainduac berac igortcen gaitu animalia ttipitto hunen gana, cer eguin behar dugun iccasterac, erraiten duela. Vade ad formicam (...). Çoaz naguia chinhaurria gana, eta consideraitçatçu haren bideac eta bidescac, ioan-ethorriac etaitçulinguruac, nequeac eta trabailluac, eta iccassico duçu çuere nola beharduçun aitcinerat eta bethiere bici, ibili etagouernatu. Harc eracusleric eta quidariric gabe, berac bere buruz viltcen du vdan, neguaren iragaiteco behar duen mantenua, bazca eta bihia. Eta bihi hura gordetcendu lurrean barrena, berac eguinicaco gambaretan, eta bihiteguietan. Eta hainda çuhur eta goithatu, ecen campohan deus ecin içanez, bere vilduetara, vildu behar duenean, lehenic hozitu behar duen burutic hasten baitçaica bihiari: ceren bertcela sorliteque bihi hura, buztan liteque, belhar bihur liteque: eta guero handic harat, alfer-lan gaertha lequidicayo, bere leheneco çuhurtcia guztia.

Aldaketak, gutxi gorabehera, Leizarragarengan aurkitu ditugun berberak dira:

- $<$ ç $>\rightarrow<\mathrm{z}>$ : çuhurtciaz $>$ zuhurtziaz, horniçoiñaz $>$ hornizoinaz, Çoaz $>$ Zoaz, duçu

$>$ duzu, etab. Ordea, jatorrizko $<\mathrm{zi}>$ bakarra gorde du: hozitu $>$ hozitu.

testuaren gain-gainean. Frogatzen erraza den bezala, gehienak 2. argitalpena aurrean izanik egindakoak dira. Derradan, bidenabar, gehienetan bat datozela Villasantek bere argitalpenean egindako aukerekin: honek esan nahi du erabiltzen ari garen argitalpen modernoa bertsio kutsatu bat dela, ez baita axola gutxiko kontua. 
- $<\mathrm{tc}>$ eta $<\mathrm{tç}>\rightarrow<\mathrm{tz}>$ : çuhurtciaz $>$ zuhurtziaz, viltcen $>$ biltzen, igortcen $>$ igortzen, itçatçu $>$ itzatzu, itçul-inguruac $>$ itzul-inguruac, aitcinerat $>$ aitzinerat, etab.

$\cdot<\mathrm{i}>\rightarrow<\mathrm{j}>/ \#-\mathrm{V}$ : ioan-ethorriac $>$ joan-etorriac.

$\cdot<\mathrm{y}>\rightarrow<\mathrm{i}>/ \mathrm{V}-\mathrm{V}$ : lequidicayo $>$ lequidicaio.

- $<\mathrm{h}>$ kendu: behar $>$ bear, campohan $>$ campoan, belhar $>$ belar. Halaber: th, $l h>$

$t$, l: ioan-ethorriac $>$ joan-etorriac, bethiere $>$ betiere.

- Grafia bikoitzak bakundu: iccasterac $>$ icastera, iccassico $>$ icasico.

- $<\mathrm{v}>$ edo $<\mathrm{u}>\rightarrow<\mathrm{b}>$ : gouernuaz $>$ gobernuaz, viltcen $>$ biltzen, vildu $>$ bildu, etab.

- Aditza eta laguntzailea bereizi: erranendu > erranen $d u$, consideraitçatçu > considera itzatzu, etab.

- Marratxoaz lotutako atzizkia biltzea: bihi-teguietan $>$ bihiteguietan.

- $<\mathrm{rtc}>\rightarrow<\mathrm{rc}>$ : bertcela $>$ bercela .

- Zuzenketak: iccasterac > icastera (1643 iccastera), çuere > zuc ere (1643 çuc ere), gaertha $>$ guertha.

- Irakurketa txarrak edo sasi-zuzenketak: quidariric > guidariric, gambaretan > gambaraetan, deus ecin > ecin deus, baitçaica > batzaica.

- Aldaera aldaketak: eta $>$ ta, hunen $>$ onen, guztia $>$ gucia .

\section{Etxeberri Ziburukoa}

Haranbururekin batera Etxeberri da Larramendik aipatu zuen lehenengo euskal idazlea, "Apendiz de la poesía bascongada" deritzan Imposible Vencido-ko atalean, ezaguna denez, eta honela aurkezten digu:

Hállanse exemplares [de este segundo modo de versos] en el dialecto labortano, en que han sido más curiosos y aplicados, y por esso tienen algunos libros impressos en prosa y verso. Entre los demás se aplicó especialmente el doctíssimo Juan de Echeberri, Doctor Theólogo, que tuvo numen particular para componer en verso bascongado, como se reconoce assí en el librito intitulado Noelac, eta bercé cantá espiritual berríac, como en el otro, que es de mayor volumen y se intitula Manual devocionezcoa, edó ezperén orén oró escúetan erabiltzeco liburuchoá, Escárazco versután eguiñá, eta guztiá bi partetán bereciá (Larramendi 1729: 374-375).

$H H$-aren hitzaurrean ere bi liburuen berri ematen du:

Otro librito en 12. impresso en Bayona Año de 1630, aunque con muchas erratas. $\mathrm{Su}$ autor Joanes de Echeberri, Doctor Theologo. Contiene 250 pág. y está todo él en verso. Su título Noelac, eta berce canta Espiritual berriac. El assunto es la Vida de Christo y sus principales misterios, especialmente su Nacimiento, alabanzas de la SS. Trinidad a quien llama, y bien, Hirurtasuna, ${ }^{24}$ y de otros Santos. De su bascuence dice con razón uno de los Aprobantes:

Escaldunac hel bequizquit

Haren ohoratzerá,

Ceren escara eman duen

Erdararen ganerá.

\footnotetext{
${ }^{24}$ Esan gabe doa hirurtasuna s.v. trinidad jasota dagoela.
} 
El mismo autor tiene otro volumen mayor, también en verso, de assuntos muy útiles, de que hago mención en el Arte del Bascuence. El exemplar que yo leí está en la Librería del Colegio mayor de Cuenca en Salamanca.

Bietatik bat ere ez da agertzen Larramendiren eskuzko liburu zerrendan, baina Manual Devotionezcoa behintzat bai Landa eskribauak egindakoan (Altuna 1984: 75, 69. zb., Iturriaga 1992: 158), hurrengo ohar honen pean ezkutatuta, Altunak (op. cit. 72) ederki ikusi bezala: ${ }^{25}$

It. otro libro de bascuence en pasta de octavo, intitulado: Manual de Devociones. Sin autor. Impreso en Burdeos por Mongiron Milagez, el año de 1669.

\subsection{Larramendiren Noelak}

Larri ibiliko gara Larramendik zein argitalpen erabili zuen jakiteko. Lehenik, ezagutzen dugun lehenengo argitalpena 1645ekoa da, baina Vinsonek uste zuen (18911898: 67, 15a zb.), eliz baimenak 1630ekoak direla kontuan izanik, urte hartan bertan edo hurrengoan —ziurrenik Millanges, Etxeberriren lehen argitalpenen ohiko inprimatzailearenean - kaleratutako bat egon zela egin zuen, hamabost urtez argitaragabe irauteari ezinezkoa baitzeritzan. Bigarrenik, argitalpen asko ditu (zortzi bai, Vinsonen arabera), 1645ean hasi eta zehaztu gabe dagoen XVIII. mendeko dataren batera arte: ${ }^{26}$ bukaera non jartzen dugun eta denak edo gehienak Larramendik ezagutzeko modukoak dira, beraz. Vinsonek (op. cit. 73, 15i zb.), gramatikako oharrean oinarriturik eta hango testua berak ezagutzen zituenekin erkaturik, iradoki zuen 1699ko Maffre-ren argitalpena ${ }^{27}(=15 \mathrm{~d})$ erabili zukeela.

Dena dela, Vinsonen hipotesia $H H$-ko xehetasunekin konparatu bezain laster, ohartzen gara gauzak zailxeagoak izan daitezkeela: Larramendiren arabera, eskuztatu zuen alea Baionan 1630ean ateratako 250 orrialdeko eta Noelac... izeneko in-12 bat zen. Izan ere, alde batetik, birritan (gramatikan eta hiztegian) errepikatzen duen izenburua denez gero, Noela... deritzen $15 \mathrm{~g}, 15 \mathrm{~h}$ eta $15 \mathrm{i}$ argitalpenak alde batera uztekoak dira. Bestetik, orrialde kopuru bera 15f-n bakarrik (eta, gehienera jota, 251 dituen 15b-n) aurkitzen da, 15c, 15d eta 15e-k 240 edo 241 dituzten bitartean. Bestetik oraindik, in-12

\footnotetext{
25 Badirudi, beraz, Salamancan erabilitakoaren ondoren beste ale bat erdietsi zuela, baina berandu apika. Ez dago honen arrastorik Loiolako Bibliotekan (Iturriaga 1992).

${ }^{26}$ Ik. xehetasunak (Fauvet inprimatzaile familiaren gorabeheretan oinarrituta) Vinsonen 15i zenbakian. Beraren ustez, Etxeberriren Noelac "ont cessé san doute d'être réimprimés après la publication des Cantico spiritualac".

27 Vinsonek zehaztu bezala (1891-1898: 15i), hau liburu-saltzailea da, ez argitaratzailea; Akesolori (1970: 12) "Maffre-ren inprimerian" itzuri zitzaion, ostera.
} 
bakarra $15 \mathrm{~g}$ da, eta gainerako guztiak in-8. Eta, azkenik, Baionan atera ez zen bakarra Bordeleko 15b da. Dakusgunez, datuek aldez bederen elkar ezeztatzen dute, argitalpen bakar bat seinalatu beharrean.

Dataren arazoa nahita akabantzarako utzi dut: nekez sinets daiteke Larramendik ezagutzen ez dugun lehen argitalpen hipotetiko hura ezagutu zuenik; aitzitik, pentsatu behar dugu datagabeetatik bat izanik, Vinson bezala baimenetan oinarritu zela liburuaren data emateko. ${ }^{28}$ Eta hau badateke argudio indartsu bat Vinsonen hipotesia, alegia 1699koa (15d) erabili zuela, deusezteko, zeren eta datagabe bakarrak 15f, g, h eta i baitira.

Laburbil dezagun goiko erkaketa anitzetatik atera daitekeena: tamainaren (in-12) datu garrantzitsuarekin bat datorren bakarra $15 \mathrm{~g}$ bada ere, ezinezkoa da izenburua (Noela...), orrialde kopurua (204 or.) eta datarengatik. ${ }^{29}$ Izenburuak eta orrialde kopuruak, berriz, 15f hautagai on bilakatzen dute, nahiz tamaina (in-8) desegokia izan. Ondorioz, 15f bera ez bada (Larramendik tamainan huts egin zuela suposaturik) ${ }^{30}$ Vinsonek bildu ez zuen —eta ziurrenik Paul Fauveten eskutik ateratako- argitalpen bat izan zela pentsatu behar genuke. Zalantza hauek behin betiko uxatzea oso garrantzitsua izan daiteke, Larramendik liburuak huts asko zituela esan baitzuen, besteak beste. ${ }^{31}$

\footnotetext{
${ }^{28}$ Gogoratu Axularrekin gauza bera egin zuela. Ez nator bat, beraz, Atutxarekin (1999: 305), batez ere berak aurkezten duen ziurtasunarekin.

${ }^{29}$ Vinsonen arabera, argitaratzailea (Jean Fauvet) 1731-1760 artean aritu zen lanean, eta esan gabe doa Larramendik gramatikan aipatzeko 1729 baino lehenagoko bat behar dugula: Paul Fauvet, berriz, 15f-ren egilea, 1700ean hasi zen inprimatzen.

${ }^{30}$ Oso hipotesi egiantzekoa da: ohartu in-12 bakarra (15g, Vinsonek ezagutu zuen argitalpenik handiena: 58 x $112 \mathrm{~mm}) 204$ orrialdetakoa eta in-8-ko guztiak (41'5-45 x 95-98 mm) 240-250 orrialdetakoak direla, tamaina eta orrialde kopurua elkarri egokituta; Larramendik ezagutu zuen aleak, ostera, tolestaketa berekoa izan arren (in-12), txikien orrialde kopuru bera (250) dauka. Bide batez, hau ez da batere harrigarria, zeren paperaren tamainaren arabera tolestaketa bereko bi liburu tamainan oso ezberdinak izan baitaitezke (cf. McKerrow 1998: 188).

${ }^{31}$ Edozein moduz, Akesoloren arabera (1970: 12) ateraldi guztiak daude hutsez josirik
} 
Artean, 15f argitalpena erabili dut. $^{32}$ Hona hemen Imposible Vencido-n eskaintzen dituen bertsoak, hartakoekin erkatuta:

Larramendi (1729: 375-377)

Innocénten Amen dolorearén gañeán Noela.

Innocénten Ama ónac

Guztiz ciren arritú,

Soldaduac cirenéan

Bethleená hurbildú.

Icí aldurá ethorrí

Citzaien bihotzera,

Nigarra beguirá, eta

Icará gorputzerá.

O háurchoac (errán zúten)

Zúec badá hain sarri

Galdú behar zaituztégu

Bihotzen hiragarri?

Madaricá dadillála

Herodes tyranoá,

Ceñác hambát altarátzen

Baitú guré gozoá.

Nolá bátzuc haurrequin ihessi aviatú cirén.

Bátzuc aviatú cirén

Haurrequien ihessí,

Lastér ordéan citúzten

Burréüec ardietsí.

Berealá beré hármac

Ateratú cituztén,

Eta háurchoei lehónac

Leguéz iaucí citzaistén.

Bessoac cedutzatelá
Etxeberri (Noel 85-88, Akes 75-76)

Iunocenten Amen dolorearen gañean.

Noëla.

Innocenten Ama onac

Guztiz ciren harritu,

Soldaduac cirenean

Bethleena hurbilldu.

Ici aldura ethorri

Citçaien bi]t[hotcera,

Nigarra beguira, eta

Ikhara gorputcera.

O Haurchoac(errançutê),

Çuec bada hain sarri

Galdu behar çaituztegu,

Bihotcen hiragarri?

Madarica dadillala

Herodes Tyrannoa,

Ceñac hambat altaratcen

Baitu gure ${ }^{33}$ goçoa.

Nola batçuc haurrequin ihessi auiatu ciren.

Batçuc auiatu ciren

Haurrequien ihessi,

Laster ordean cituzten

Burreuet [sic] ardiatsi.

Bere hala bere harmac

Atheratu cituzten,

Eta haurtchoei lehonac

Leguez iauci citçaizten.

Besoak cedutçatela

${ }^{32}$ Urquijoren alea (JU 1796 C.F. 72, Koldo Mitxelena Kulturunea, Donostia). Bat dator zeharo Vinsonek eman ezaugarri guztietan — salbu eta "12 pour 122", gurean 128 (eskuz ziurrenik: 121ak 1aren gainean 7 duela dirudi), " 8 pour 208 ", gurean 08 , eta "118 pour 218 ", gurean 18 berak ikusi alearekin. Halaz ere, hasierako orrialde zenbait (17-24) lekuz kanpo daude, liburuaren hasieran baina ongi zenbatuta; gainerantzean ez du ezer falta, aurreko argitalpenetan ez dagoen zatitik 241-242 orria izan ezik. OEH-ak Akesoloren argitalpena (1970) erabiltzen du: ale zahar ezberdin zenbait erkatuaz — eta grafia bateratu eta gaurkotuazegindakoa da eta horregatik, besteak beste, ezberdintasun handi-txikiak kausitzen dira $15 \mathrm{f}$ eta honen artean. Dena dela, laguntza modura aipamen guztietan, 15f-ren orrialde zenbakiaz gainera, argitalpen modernoarena jarriko dut, "Akes" laburdurarekin, 15f-n lehendabizikoz agertzen diren eta Akesolok berean sartu ez dituen hiru kantetan izan ezik: "Verbum caro" (241-245. or.), "Claritates guçia..." (245-246. or.) eta "Jesus Haurtcho larru..." (249-250. or.).

${ }^{33}$ Akesolorenak (1970: 75) bere dio. 
Aireán alchatuác,

Amec ecártzen citúzten

Aitziñerá escuác.

O burréu cruélac, andré

Nigartsúec diusté,

Guré haur gaisóec Zuei

Cer eguín darotzué?

Baldín hutsíc badá, dítuc

Guztíac guré aldetíc,

Eta ez ezagutzaric

Eztutén haurretatic.

Gurí iguzquigutzúe

Heriozcó colpeác,

Etá utz biciric guré

Jaió berrí humeác.

Bañán hargatíc etzíren

Bátere guibelatú,

Aitzitíc escua zuten

Háurretara hedatú.

Bátac thira, bérceac thíra,

Hari círen guduán:

Soldaduá garaitzén-da

Ordean azquén buruán.

Bere harmá sartzen dio

Cruelqui gorputzeán,

Eta haur gaisoá uzten

Hedatua lurreán.

Zaurietaric Cerión

Issurrica odolá,

Iturrián ur garbia

Chorroetaric nola.
Aairean [sic] altchatuac,

Amec ekartcen cituzten

Aitciñera escuac.

O Burreu curelac, ${ }^{34}$ andre

Nigartsuet [sic] diuste,

Gure haur gachoec cuei [sic]

Cer eguin darotçue?

Baldin hutsic bada, dituc

Guztiac gure aldetic,

Eta ez eçagutçaric

Eztuten haurrenetic.

Guri iguzquigutçue

Heriozco colpeac,

Eta utz biciric gure

Iaio berri umeac.

Bañan hargatic etciren

Batere guibelatu,

Aitcitic escua çuten

Haurretara hedatu.

Batac thira, berceac thira,

Hari ciren guduan:

Soldadua garaitcen da

Ordean azken buruan.

Bere harma sa[r]tcen dio

Curelqui gorputcean,

Eta haur gachoa uzten

Hedatua lurrean.

Caurietaric [sic] cerion

Issurica odola,

Ithurrici [sic] ur garbia

Corrotetaric [sic] nola.

\subsection{Larramendiren Manuala}

Ez da samurragoa Manual-arekikoa. Hasteko, Larramendik bi ale ezberdin eskuztatu zituen: lehena, gramatikan erabili eta hiztegian aipatzen duen Salamancako Cuencako Ikastetxe Nagusiaren bibliotekakoa, eta bigarrena bere liburutegian Altunak (1984: 72; ik. Iturriaga 1992: 158 ere) identifikatu zuena:

Ytt. otro libro de Bascuenze empasta de octauo, Yntitulado: Manual de Deuociones. Sin Autor. Ympreso en Burdeos por Mongiron Milagez, el año de 1669.

\footnotetext{
${ }^{34}$ Akesolok (1970: 75) kruelak irakurtzen du. Halaz ere, 15f-ko irakurketa ziurra da, zeren eta lehentxeago (84. or.) Cureltassun baitakar, berriro ere Akesolok (ib. 74) krueltasun irakurria, eta hemen berton, beherago, Curelqui irakurtzen da (Akesolok kruelki).
} 
Loiolan zegoen ale hura, ${ }^{35}$ bigarren argitalpenekoa (Vinson $\left.14 \mathrm{~b}\right),{ }^{36}$ argi eta garbi ez da $H H$-an baliatu zuena, eta ziurrenik beranduago erdietsitakoa izan zen. ${ }^{37}$ Salamancakoa erabili zuen, beraz, baina hartaz ez digu ez gramatikan, ez hiztegian berri zehatzik ematen, kasu honetan ezertarako ez den izenburu osoa izan ezik, zeinagatik $1627 \mathrm{koa}$ (Vinson 14a) ala 1669koa (14b) ote zen ez baitakigu, ${ }^{38}$ nahiz hau ere bigarrenekoa izatea egiantzekoagoa dirudien.

Dena dela, hona Imposible Vencido-n (Larramendi 1729: 378) aipatzen dituen bertsoak eta bigarren argitalpenekoak (1669: I, 12) (39 $^{39}$ aurrez aurre ezarriak:

$$
1729
$$

Zure leguéac háuchec díre, Sinaico mendian

Berce ordúz Moisen emanac Arabian.

Jainco bat onéts-ezác, eta adóra devotqui,

Etá arén icenaz ez ciñíc eguin vanoqui.

Gueiágo beguirázac igandeá sainduquí,

Eta burasóac ondrá, bicí-adín lucequi.

Nihór hill eztezaquelá, ez bihótzez gaitzetsi,

Ecén vengántzen Jaincoá ni behár nauc sinetsí.

Paillardiza iguinari eguioquec ihesá,

Guztíz ere ez desirá lagunaren Esposá.

Bercerén oná hain guttí beharco-dúc iduquí,

Guztiz ere hauzoarén ontasuna ez uqui.

Fiñeán mihiari emoc guardià, ezten guezurtí,

Eta aicén, falseria irauztera, beldurtí.

Hauc bi manamendutara biltzen dituc laburquí,

Ceñac gogoan har ahal baitatzaquec errazquí.
1669

Çure legueac hautchec dire, Sinaico Mendian,

Berce orduz Moiseri, emanac Arabian.

Iongoicobat onhetz eçac, eta adora deuotqui,

Eta haren icenaz ez ciñic eguin vanoqui.

Guehiago beguira çac igandea saiñduqui,

Eta burassoac ondra, bici adin lucequi.

Nihor hill ezteçaquela, ez bihotcez gaitcetsi,

Ecen vengantcen Iaincoa, ni behar nauc sinhetsi.

Paillardiça higuinari eguioquec ihessa, Guztiz ere ez desira lagunaren espossa.

Berceren ona hain guti, beharco duc iduqui,

Guztiz ere hauçoaren ontassuna ez vqui.

Fiñean mihiari emoc guardia, ezten gueçurti,

Eta aicen falseria irauztera beldurti.

Bi manu Principalenac.

Hauc bi manamendutara biltcen dituc

\footnotetext{
${ }^{35}$ Orain, Iturriaga 1992ren arabera, ez dago.

${ }^{36}$ Atutxak (1999: 237, 7. zb.) ez du informazio hau erabiltzen, Larramendik zein argitalpenez diharduen erabakitzeko. Oker dabil, bidenabar, Larramendi denboraren aldetik Egiategiren ondotik ipintzen duenean (ib. 236), "liburu honen [Manual-aren] berri dakarren lehena" izateko ohorea zuberotarrari emanez, eta huts bera egiten du Noelac-i dagokionez (ib. 242).

${ }^{37}$ Oker ez banago, ez da agertzen Larramendiren zerrendan (Tellechea-Idigoras 1966a).

${ }^{38}$ Vinson bera ere (1891-1898: 67, 14b zb.) ez da ezer esatera aurreratzen.

${ }^{39}$ Eskura ditudan bi iturriak, Hordagoren faksimilea (1978) eta Altunaren argitalpena (1981) bertatik eginak dira biak.
} 
Jainco bat onets-ezac gauzá guztién gañetic,

Eta Christau laguna ez heronéz beheretic. laburqui,

Ceiñac gogoan har ahal baitetçaquec errachqui.

Iongoicobat onhetz eçac gauça guztien gaiñetic,

Eta Christau laguna ez heronez beheretic.

\subsection{Etxeberri transkribatzen}

Erkaketa honetatik, funtsean ezaugarri berberak aurkitu arren, aurrekoetatik baino informazio gehiago erdiesten dugu, guztiz Noelak liburutik, zeren eta huts aski dituenez, ohiko aldaketez gain zenbait testu zuzenketa ere ikusteko parada ematen baitigu. Kontuan izan bedi, dena den, bi testuak Gramatikakoak direla eta, horregatik, $H H$-ko eta Corografia-ko grafi sistemarekin ezberdintasunen bat izango dela:

- $<c ̧>\rightarrow<\mathrm{z}>$ : çuec $>$ zuec, çaituztegu $>$ zaituztegu, çure $>$ zure, eçac $>$ ezac, çac $>$ zac, ezteçaquela $>$ eztezaquela, paillardiça $>$ paillardiza, hauçoaren $>$ hauzoaren, gueçurti $>$ guezurti, etab.

- $<\mathrm{tc}>$ eta $<\mathrm{tç}>\rightarrow<\mathrm{tz}>$ : citçaien $>$ citzaien, bihotcera $>$ bihotcera, batçuc $>$ batzuc, bihotcez $>$ bihotzez, gaitcetsi $>$ gaitzetsi, vengantcen $>$ vengantzen, biltcen $>$ biltzen, etab.

- $<\mathrm{tch}>\rightarrow<\mathrm{ch}>$ : haurtchoei $>$ haurchoei, altchatuac $>$ alchatuac, autchec $>$ hauchec.

- $<\mathrm{ch}>><$ is $>$ : gachoec $>$ gaisoec, gachoa $>$ gaisoa $^{40}$

- $<\mathrm{I}>\rightarrow<\mathrm{J}>/$ \# - V: Iaincoa $>$ Jaincoa, Iaio $>$ Jaio, baina iauci.

- $<\mathrm{i} \tilde{\mathrm{n}}>,<\mathrm{ill}>\rightarrow<\mathrm{in}>,<\mathrm{il}>/-\mathrm{C}$, baina $<\mathrm{iñ}>\rightarrow<\tilde{\mathrm{n}}>/-\mathrm{B}$ : saiñduqui $>$ sainduqui, ceiñac $>$ ceñac, gaiñetic $>$ gañetic; hurbilldu $>$ hurbildu.

- $<\mathrm{h}>\mathrm{kendu}$ : bere hala $>$ bereala, haren $>$ aren, guehiago $>$ gueiago, higuinari $>$ iguinari, baina hurbildu, bihotzera, behar, hiragarri, ihessi, etab. (Noelak-en oso sarri). Cf., ostera, umeac $>$ humeac, Hegoaldeko ohiturari atxikita. Bestalde, onhetz $>$ onets (bi bider), sinhetsi $>$ sinetsi, bai eta $<\mathrm{th}>\rightarrow<\mathrm{t}>\mathrm{k}(\mathrm{h})>\mathrm{c}$, qu: atheratu $>$ ateratu (baina ethorri, thira); ikhara $>$ icara, ekartcen $>$ ecartzen, azken $>$ azquen.

- <ss> bikoitza bakundu: burassoac > burasoac, ihessa $>$ ihesa, espossa > esposa, ontassuna $>$ ontasuna, baina ihessi, issurica (Noelak-en).

- $v$ eta $u$-ren erabilera normaltzea: $:^{41}$ auiatu $>$ aviatu, deuotqui $>$ devotqui, vqui $>$ uqui.

- Aginterazko laguntzailea biltzea: beguira çac > beguirazac.

- Txistukarien "zuzenketa": citçaizten > citzaisten, onhetz > onets (bi bider).

- Argitalpenen erratak edo irakurketa txarrak: bithotcera $>$ bihotzera, burreuet $>$ burreüec, Aairean $>$ Airean, Nigartsuet $>$ Nigartsuec, cuei $>$ Zuei, haurrenetic $>$ haurretatic, satcen $>$ sartzen, Caurietaric $>$ Zaurietaric, Issurica $>$ Issurrica, ithurrici [ithurrica-ren ordez] > iturrian, corrotetaric [sic, ç-ren ordez] > chorroetaric (Noelak-en). Moiseri > Moisen, baitetçaquec $>$ baitatzaquec (Manualean).

\footnotetext{
${ }^{40}<$ is > zalantzazkoen bermea dukegu honelako aldaketetan (Urgell 2001b: 144-149).

${ }^{41}$ Hemen igartzen da, besteak beste, 1729tik 1745ra dagoen aldea: ez ditu $<\mathrm{v}>\mathrm{ak}<\mathrm{b}>$ bihurtzen.
} 
- Aldaera aldaketak: ardiatsi $>$ ardietsi, curelac $>$ cruelac, curelqui $>$ cruelqui (Noelak-en). Iongoico > Jainco (bi bider, cf. artean Iainco 1669koan ere), guti > gutti, errachqui > errazqui (Manual-ean).

\section{Materre}

Honako hau da bere bildumako euskaldun berri bakarrari eskaini zion laudorio estimagarria:

Otro volumen del mismo tamaño, que contiene la Doctrina Christiana, muchas oraciones y uno como Directorio de Marineros en Bascuence hermoso, cual es el de Sara en Labort, y tanto más estimable cuanto su autor, no siendo bascongado, aprendió la lengua con toda perfección. Llámase el R. P. Esteban Materre de la Seráfica Orden de N.P.S. Francisco de la Observancia, guardián que fue del Convento de Avela: ${ }^{42}$ y entre sus aprobadores, uno es P. de Axular, de quien hablaremos luego. Al principio está una adición de otro autor no de tan lindo bascuence. ${ }^{43}$ Es del año 1616, y está impreso en Bayona (1745: xxxv).

Liburua ez da agertzen Larramendiren bibliotekaz ditugun zerrendetan eta, hortaz, $H H$-ko datuon arabera bakarrik ezagutzen saiatu behar gara. Materreren liburuak, agi denez, bi argitalpen izan zituen: lehena Bordelen Petri de la Court-ek egina dateke 1617an, eta bigarrena, Vinsonek ezagutu bakarra (1891-1898: 51-54, 11. zb.), 1623an Bordelen Iacques Millanges-ek egina.

Bion artean hautatzekotan, Vinsonek (ib. 51, 11a zb.) ez du zalantzarik: "Larramendi, qui avait probablement sous les yeux un exemplaire sans titre, s'en sera rapporté aux dates des approbations ecclésiastiques. Il n'y avait d'imprimeur à Bayonne ni en 1616 ni en 1617". Hauxe dukegu arrazoirik indartsuena, alegia, Larramendik aipatutako "uno como Directorio de marineros" hura "Marinelec nola eguin behar dituzten bere othoitçac itsasoan dabilçan demboran“ deiturikoa (1623: 325-353) izan behar dela, eta hau -Fr. Aegidius Grenier baimen egile berrietatik batek dioenez (1623: 179-180)— 2. argitalpenean dotrinari erantsitako otoitz bilduman dago.

Erkaketarako, beraz, 1623koaren ale baten kopia mikrofilmatua erabili dut. ${ }^{44}$

\footnotetext{
${ }^{42}$ Sic, P. de Guilantenak “Reuleco Gardiana” dio.

${ }^{43}$ Cf. Vinson (1891-1898: 53): “Je ne sais ce que peut être l'addition 'd'un autre auteur', dont parle Larramendi".

${ }^{44}$ Oxfordeko Bodleian Library-ko alea ( $8^{\circ}$.M.30.Th.SELD), OEH-ak erabiltzen duen bera, alegia.
} 


\section{Haranburu}

Gramatikan (Larramendi 1729: 279), Etxeberrirekin batera "Fr. Juan de Aramburu, en su librito devocino Escuarra, Mirailla eta Oracinoteguia" aipatzen badu ere, ez dago gero - guztiz $H H$-aren hitzaurreko liburu zerrendan- liburu honetaz beste aipurik. Dena dela, pentsatzekoa da noizbait eskuartean izan zuenez gero, ${ }^{45}$ hiztegirako ere baliatu zukeela.

Vinsonen arabera (1891-1898: 73-75, 16. zb. eta 540-541) liburua lehenengoz 1735ean "Bordelen, P. de la Court erregueren ardutaco [sic] imprimatçaillea baithan" argitara zen. Ondoren, beharbada lau berrargitalpen izan zituen: bata 1641 edo 1642an, bigarrena 1660 inguruan Harizmendik paratua, hirugarrena 1690ean eta laugarrena (ziur aski aurrekoaren legez kanpoko kopia) urte berean, baina bibliografoak azken biak baino ez zituen ezagutzen eta, gainera, eskuztatu ahal izan zituen ale guztiek hasiera falta zuten.

Berak adierazi bezala (op. cit. 74, 16a zb.), dena dela, lehen argitalpenean ez dagoen Te Deum laudamus-aren euskal itzulpenaren lehen bi bertsoak aipatzen ditu Larramendik. Itzulpena, Debocino escuarra-ren hirugarren argitalpena —-"arrimo hobean" jarria, berregileak hitzaurrean dioenez— bezala, Larramendik bestela pentsatu arren Harizmendirena da, lehendabizikoz honen Ama birjinaren ofizioa-n (1660: $73 \mathrm{t}$. hur. $)^{46}$ argitaratua, eta horregatik nahitaez 1660 baino lehenagoko argitalpenak bederen erabat alde batera utzi behar ditugu hemen. ${ }^{47}$

\footnotetext{
${ }^{45}$ Eta hiztegia hasieratik egiten hasi zenez gero (cf. Urgell 2002: 633-634).

${ }^{46}$ Liburu honen lehen argitalpenaren data hau ziurra da, Vinsonek bere argitalpena kaleratzear zuela agertu zen Bodley Liburutegiko ale bakarraren arabera. Halere, Vinsonek behin-behineko datatzeak (1658, baimenetan oinarriturik) badirau hainbat lekutan: $O E H$-an, esate baterako.

${ }^{47}$ Erkaketa, Vinsonek egindakoaz gainerakoa, egin gabe dago, baina Kerejetak (1991: 867, 8. oh.) ohar interesgarri zenbait eskaini dizkigu.
} 
Erkaketarako, 1690eko argitalpenaren kopia mikrofilmatua baliatu dut, baina ale honek orrialde asko falta ditu. ${ }^{48}$ Oraingoz, erkagai hoberik aurkitu ez eta Larramendik aipatutako bertsoak Harizmendiren Virginaren officioa-ko bertsioarekin erkatuko ditut:

\section{Larramendi}

Jaungoicoá zu zaitúgu

Bihótz osóz laudatzén,

$\mathrm{Zu}$, záitugu gueuré

Jáuntzat

Ahalaz defendatzén.

Aitá bethierecoá

Ceren baitzará segur,

Andic emaiten darótzu

Lurrác ohoréz agür, \&c.
Harizmendi

Iaungoicoa, çu caitugu

Bihotz ossoz laudatcen:

$\mathrm{Çu}$ çaitugu gueure Iaunçat.

Ahalaz defendatcen.

Aita bethierecoa,

Ceren baitçara segur,

Handic emaiten darotçu,

Lurrac ohorez agur.

Aldaketak ohikoak dira: $<$ ç $>\rightarrow<\mathrm{z}>,<\mathrm{tc}>$ eta $<$ tç $>\rightarrow<\mathrm{tz}>,<$ ss $>\rightarrow<\mathrm{s}>($ ossoz $>$ osoz), hitz hasierako $<\mathrm{IV}>><\mathrm{JV}>,<\mathrm{h}>$ kentzea (Handic $>$ Andic) eta $<$ nç $>\rightarrow<$ ntz $>$ (Iaunçat > Jauntzat).

\section{Argaignarats}

Avisu liburu galduaz ezagutzen ditugun xehetasun gutxietarik batzuk behintzat Larramendiri zor dizkiogu (ik. Vinson 1891-1898: 84, 21. zb.):

Otro volumen en 12 . de 572 pág. que contiene en doce capítulos admirables y muy eficaces desengaños. Su autor, Pedro de Argainarats, sacerdote y predicador ordinario de Ciburu. Imprimiose en Bourdeaux, año 1641.

Izena osorik, Vinsonek dakarrenez, Avisu eta exortacionea [sic] probetchosac bekhatorearentçat, nola artha principalena beharduen bere arimaz, eta ez bere gorputçaz, contricionearen eguiteco, eta manamendua gaifiean [sic, manamenduen gaiñean-en ordez] conscienciaren examinatceco artearequin, P. de Argainarats, aphez eta Ciburuco predicari ordinarioac eguinac da eta, oraingoz, egile beraren beste lana

\footnotetext{
${ }^{48}$ Jatorrizko alea Lazkaoko beneditarren komentuan gordetzen da. Honako orrialde hauek falta ditu: 59-60, 83-96, 137-144, 161-168, 185-194, 305-338, 351-352 eta 480tik aurrera (485raino-edo). Gainerantzean, badirudi Vinsonek aipatzen duen 16e argitalpena dela, zeren eta, berak ematen dituen erkagaietarik, honek bezala habea eta (26. or., 9-10. 1.), Ceruan (ib., 12. 1.), Eztugu (ib., 14. 1.) irakurtzen baititu, eta ez 16d-k bezala hastea eta (26. or., 17. 1.), Cervan (ib., 19. 1.) eta Extugu (ib. 21. 1.), eta ez dakar Te Deum Laudamus aipatua 199. orrialdean, 16d-k bezala; 16e izatera, 188. orrialdean egon beharko luke, baina peitu dugu, esan bezala. Alabaina, 16d-k bezala laudacen eta (29. or., 14. 1.) irakurtzen du, eta ez landaco eta (29. or., 9. 1.) 16e-k bezala; eta ez hirur (26. or., 21. 1.) 16d-k bezala, ez hitur (27. or., 4. 1) 16e-k bezala, hirurec (27. or., 4. 1.) baizik. Vinsonek datuak trukatu ez baditu, beste argitalpen bati buruz mintzatu beharko genuke, 16e-tik oso gertu dagoen, baina honek baino huts gutxiago daukan batez, hain zuzen. Erkaketa honetako datuak Amaia Olabarriaren $(O E H)$ laguntza ordainezinari zor dizkiot.
} 
(Devoten breviarioa, Baiona, 1665) soilik daukagu $H H$-an haren hizkuntzak aztarnaren bat utzi ote zuen asmatzen saiatzeko. Lanbide gaitza, inolaz ere.

\section{Gasteluzar}

Euskara txit ederreko liburutzat izan zuen Larramendik:

Otro volumen en 12. de 479 pág. que contiene seis partes, y en ellas muchas oraciones y prácticas cristianas, las más en verso: trata de los novísimos, de los Sacramentos y Mandamientos, muchos Hymnos, Salmos, especialmente los penitenciales, y una Doctrina Christiana muy breve, todo en bellísimo bascuence. $\mathrm{Su}$ Autor es el Padre Bernardo de Gasteluzar de la Compañía de Jesús. Está impreso en Pau año de 1686.

Argitalpen bakarrekoa da, Vinsonen arabera (1891-1898: 134-135, 39. zb.), eta honek ematen dituen datuak bat datoz $H H$-koekin. Erkaketarako Bonaparteren alearen mikrofilma erabili dut. ${ }^{49}$

\section{Xurio}

Larramendik erabili zuen Iparraldeko libururik berrienetakoa da:

El Kempis o Contemptus mundi traducido por M. Chourio, Rector de San Juan de Luz, impresso Año 1720.

$H H$-an balorapenik egiten ez duen arren, beranduago, Iparraldeko idazle berrien artean Haraneder baino Xurio nahiago zuela esan zuen:

Por demasiada puntualidad en querer escribir distinguiendo los verbos de sus terminaciones con sus barritas en medio, embarazan al lector, como se ve en la reciente traducción del Combate espiritual y de la Introducción a la Vida devota de Sales; y por eso, sin esas nimiedades, se lee más corriente a Chourio en la traducción del Contemptus mundi y otras obras en este dialecto (Corografia 297).

Hitzaurreko datuak, hasieran bederen, bat datoz Xurioren lehen argitalpenarekin (Vinson 49a), baina baita Vinsonek 1720-1750 artean kokatzen duen eta azal berdina duen bigarrenarekin (Vinson 49b). Jasota agertzen da bai Larramendiren zerrendan

\footnotetext{
${ }^{49}$ EHUko Filologi Fakultatea, Gasteiz (erref. 13311). Ale osoa da, salbu eta hasierako orri bat, hots, jai aldakorren Bazkotik aurrerako zatia (iii. or.) eta egutegiaren lehenengo orrialdea (iv. or.; hurrengoa urtarrilaren 27an hasten da). Argitalpen moderno bakarra (Akesolo 1983) filologoentzat baliogabekoa da: alde batetik, “...egutegia kanpoan utzi da. Orrez gaiñera, latin utsezko puska batzu ere bai" (op. cit. 20); bestetik, jatorrizko testuaren hutsak zein diren abisatu gabe zuzendu egin ditu, eta "Letraren bat itz berean bi eratara jarri duenean ere, berdintzen saiatu gara: promes, ez promez" (ib. 21). Eta, azkenik baina ez mendreenik, arta gabeko argitalpena da, hutsez blai kaleratua, izenetik beretik hasita. Eskasiok ezagunak izan arren (eta argitalpen zaharra erraz aurki badaiteke ere, esaterako KM kulturunean: J.U. 4732), jatorrizko testua ordezkatzea lortu du (gai honetaz ik. Urgell 2000b), OEH-an adibidez.
} 
(Tellechea-Idigoras 1966a: 356, 71. zb.), bai Landarenean (Altuna 1984: 74, 43. zb.; Iturriaga 1992: 156); hauxe da azken honen oharra:

It. otro libro de a octavo en pasta en bascuence. Intitulado: Imitac[i]ón de Jesuchristo por el Mro. Chourio, Ror. del lugar de Done Juan. Impreso en Burdeos por Guillaume Boude Boe el año de 1720.

Iturriagak (1992: 41-42) egindako Loiolako Bibliotekako edukiarekiko erkaketan, jadanik 1750 eta 1788ko argitalpenak daude bakarrik. Halaz ere, eskribauaren ohar zehatzari esker, benetako lehen argitalpena dela ziur dakigu, in 8 baita, eta ez haren faltsutzea bezala in 12 .

Eskura dugun faksimilea (Hordago, Donostia, 1978) 1788ko argitalpenetik egina da (Vinson 49e); azterketarako erabili dudan alea ${ }^{50}$ askoz lehenagokoa da, ezbairik gabe; halaz ere, princeps-aren eta ondoko faltsutzearen artean bereizteko Vinsonek bildu ezberdintasunetako batzuetan bakarrik dator bat ${ }^{51}$ eta, beraz, badirudi berak uste baino gutxienez beste argitaraldi bat egon zela.

\section{Lavieuxvilleren dotrinak}

Honela aurkezten ditu Larramendik:

Dos Cathecismos, uno breve, que contiene sólo el texto, y otro más largo, que contiene la explicación de las quatro partes del texto: de la primera 26. lecciones; de la segunda 24; de la tercera 33; de la quarta 27; y además, muchas prácticas santas, exemplos e historias, que se citan de los Sagrados Libros. Es cosa muy selecta: hizólos imprimir en Bayona el Illustrisimo Señor don Pedro Guillelmo de Lavieuxville, Obispo de aquella ciudad, cuya virtud, celo y prudencia singular no puedo alabar bastantemente. Imprimiéronse Año de 1733 (1745: xxxiv).

Liburu biak jasota agertzen dira Larramendiren zerrendan (Tellechea 1966a: 356, 29. zb.) eta Landarenean (Altuna 1984: 74, 46. zb. eta 78, 204. zb.). Eskribauaren oharrak, Larramendirenak baino zehatzagoak, hauek dira, Iturriagak (1992: 156 eta 171) egin transkripzioaren arabera:

It. otro libro en bascuence en pasta de a octavo, intitulado: Aquellos que se preparan a hacer la primera Comunión en la segunda cuaresma, Diócesis de

\footnotetext{
${ }^{50}$ Eusko Legebiltzarraren Liburutegian (Amezaga 1983: 87-88, 237. zb.) gordetako alearen mikrofilma, OEH-ak erabiltzen duen berbera.

${ }^{51}$ Uste honetan bat nator Legebiltzarreko Liburutegiko adituekin (loc. cit.). Gehiago zehatz daiteke, ordea: Princeps-ean bezala, 151. or.ko 1. lerroa "eta enga-" z bukatzen da, baina faltsutzean bezala 401. or.ko 1. lerroa "ô guiçonen"-ez hasten da eta "erre/que-"“-z bukatzen, orrialde bereko azken lerroa "ça notha gabe!" da, 426. or.ko azken lerroa "tuzcoac." eta zenbatu gabeko bukaerako x. or.ko 5. lerroan "LVII. E çaicula bihotça" irakurtzen da, $t$ letra faltan.
} 
Baiona. Su autor el Padre Guillaume de Lavieusville [sic]. Impreso en Baiona por Faumet el año de 1733.

It. otro de a octavo con cubierta de lo mismo en bascuence, intitulado: Breve Doctrina para buenos christianos. Su autor Dn. Pedro Lavieuxville. Impreso en Baiona por Jaubet, el año de 1731.

CatLav txikia dela eta, Vinsonek (1891-1898: 171 eta hur., 54. zb.) ikusterik izan ez zuen lehen argitalpena 1732 edo 1733an datatu zuen, apezpikuaren agindua 1731ko ekainaren 20koa da eta. Larramendiren lekukotasuna ziur aski aintzatago hartzekoa da berak egin zuen baino, oraindik Baionan baitzegoen —eta, beraz, zuzenean lor baitzezakeen - kalera orduko. Dena dela, ez dago zalantzarik lehenengo argitalpena eskuetan izan zuela, Vinsonek zenbatzen duen bigarrena 1749koa baita. Halaz ere, ez dut bigarren hori baino argitalpen zaharragorik erdiesterik izan. ${ }^{52}$

CatLav handiari dagokionez, Vinsonek (1891-1898: 176-177, 55. zb.) hiru argitalpen jasotzen ditu, hirurak urte eta etxe berean eginak eta, dirudienez, txikikerietan baino bereizten ez direnak. Hiruren arteko erkaketa egitea ezinezkoa nuenez gero, Villasanterena (1985) baliatu dut; hau "Donostian, Urquijoren liburutegian dagoen alea" erabiliz egin dela dio argitaratzaileak (1985: 15), Urquijok ale bat baino gehiago (argitalpen ezberdinetakoak) dituela erreparatu gabe. Dena dela, Villasantek $P$. Guillaume irakurketa egiten du 15a-rekin batera (eta ez Piarres-Guillaume, 15b eta c-k bezala): badirudi, beraz, Vinsonek lehen lekuan ipinitakoa dela.

\section{Exerzizio Spirituala}

Biziki goraipatzen duen liburu honen aurkezpena itxuraz oso eskasa da:

Otro librito impresso en Bayona, sin nombre de autor y sin el año de la impressión, contiene Exercicios Espirituales y Oraciones en prosa y verso; y al último la Passión del Señor por San Matheo y San Juan, todo muy bien hablado.

Halaz ere, ez dago dudarik gutxienez 1844 arte Exerzizio Spirituala izena eraman ohi zuen eta 1851 arte-edo beti Baionan argitaratu ohi zen liburua dela (Vinson 1891-1898: 147-158, 46. zb.; ik. halaber Urquijo 1907c). Larramendiren oharra aski ondo osa dezakegu, liburua Landaren zerrendan agertzen baita (Altuna 1984: 75, 59. zb.; Iturriaga 1992: 158), Altunak (ib. 72) esan bezala, honela azalduta:

It. otro libro en bascuence en pasta manual, intitulado: exercicio espiritual. Sin autor. Impreso en Baiona p[o]r feuiueten sin su año de su impresión.

\footnotetext{
${ }^{52}$ Erabiliko dudana Urquijorena da (JU 3993a, Koldo Mitxelena Kulturunea, Donostia).
} 
Liburu honen lehen argitalpenen historia aski nahasi eta ezezaguna da, tamalez, Larramendik erabilitako alea ziurtasun osoz finkatu ahal izateko. Dena dela, ditugun xehetasun apurrak aski eta sobera dira Vinson 46a (1716) eta 46b ("M. Roquemaurel liburu saltçaillea baithan Apumayouco carrican 1718”) kanpoan uzteko eta, hasiera batean bederen, 46c aintzat hartzeko, Vinsonek egin bezala, data (berez datagabea; bibliografoak 1741 ezartzen dio zalantzaz, "tableau de comput ecclésiastique" delakoa 1742-1764 artekoa baita), lekua eta inprimatzailearen izena ("Paul Fauvet, Erregueren imprimatçaillea baitan") egokiak dira eta. Ez dago erabateko ziurtasunik, ordea: alde batetik, Vinsonek berak aitortzen du 1718-1742 bitartean gehiago egon zitezkeela, nahiz funtsean berdinak:

L'exercicio espirituala est le livre basque le plus répandu et el plus commun; c'est celui qui a été le plus souvent et le plus diversement réedité, contrefait, refait, remanié, etc. Les éditions dont le tableau de comput commence à 1742 et 1755 portent tous deux, comme la précédente de 1718 (contrefaçon de Roquemaurel), la rubrique: "deuxième édition". Il est probable que de 1718 à 1742, il y a eu plusieurs réimpressions portant toutes la même rubrique et en différant les unes des autres que par le tableau au verso du tritre (Vinson 1891-1898: 149, 46d zb.).

Bestetik, beti Vinsonen azalpenaren arabera, ez dakigu 46c-k Larramendik aipatzen duen "la Passión del Señor por San Matheo y San Juan" atala duen ala ez, beranduagokoa (1754 edo 1755ekoa) den 46d-k baduena. ${ }^{53}$ Bestetik, oraindik, 174142 ko data berankorregia izan liteke, apika, Harrieten gramatikarekin alderatuta. Eta, azkenik, Landaren oharrak "feuiueten" dioenez gero — beti bezala euskal testua halahola jasoaz-, badirudi Larramendik izan alean inprimatzailearen izena genitiboaz emana zela (cf., adib., P. Fauveten Imprimerian Etxeberriren Noelac-en $15 \mathrm{f}$ argitalpenean). Azterketa bibliografiko zehatzago baten zain, beraz, eskura izan dudana (Vinson 46c-ren oso antzekoa) $^{54}$ erabili dut konparabide gisara, Vinsonen iradokizunean —arteko denak, "tableau" izan ezik gainerako guztia berdina zuketela, alegiafidaturik.

\footnotetext{
${ }^{53}$ Dena dela, biek orrialde kopuru bera (371 or.) dutenez gero, badirudi edukian ere berdinak izan behar zutela; 46d-n Mateoren pasioa 342-357. orrialdeetan agertzen da, eta Juanena 357371.etan.

${ }^{54}$ Ik. Amezaga 1983: 69, 188. zb. Eusko Legebiltzarraren liburutegiko adituen arabera, dena dela, 1766 inguruan koka liteke: hau hala balitz, esan gabe doa Larramendirekiko erkaketa osoa burutuko denean zaharragorik aurkitzea mereziko lukeela.
} 


\section{Beriain}

Iparraldekoak ez diren liburuen artean bat bakarrik bereizi eta izenez eta izanaz aipatu zuen Larramendik hiztegiko zerrendan, atxikitzen zaion tradizioagatik eta hizkuntzaren alderdi zenbaitengatik ${ }^{55}$ haien aldamenean ezar daitekeen eta, ezbairik gabe, hiztegigilearen ustetan Hegoaldeko dotrina zahar guztietatik haiekin gehiegi galduan atera gabe pareka daitekeen bakarra, hain zuzen:

Un librito en 12. con la Doctrina Christiana primero en Castellano seguido en 83 ojas, y después en Bascuence también seguido casi en otras tantas: una y otra bien sólidamente escritas. Imprimióse en Pamplona Año de 1626, con licencia y aprobación de su Prelado, el Ilustrissimo Señor Don Francisco de Mendoza. Su autor es el Licenciado Don Juan de Beriain, abad de la Parroquial de Uterga (Larramendi 1745: xxxv).

Larramendiren aipuak, beharbada, nafarrerazko beste zenbait dotrina zaharren patu gaiztoa ekiditen lagundu zion, hari-harian egon bada ere.

Argitalpen bakarrekoa izan zen, dakigularik (Vinson 1891-1898: 63-64, 13. zb. eta 538-539, 12bis zb.). ${ }^{56}$ Liburua jasota agertzen da Landaren zerrendan (Altuna 1984: 77, 187. zb.; Iturriaga 1992: 169), nahiz Larramendik bere oharra idazteko erabili baino, itxuraz xehetasun gutxiago daukan:

It. otro mui usado de lo mismo en castellano y bascuence, intito.: Doctrina Christiana, compuesta por el Licdo. Dn. Juan de Beriain, sin que conste por falta de hojas su impresión y año.

Honen arabera, baliteke Larramendik urtea eta lekua baimenetatik ateratzea, bestetan bezala.

Goi-nafarreraren barruko ezberdintasunak agerian jartzeko, Larramendik Corografían (299. or.) Beriainen eta Elizalderen Kredoaren bertsioen zatitxo bat erkatu zuen. Gauza bera egingo dut hemen orduko transkripzio horren eta nik erabiliko dudanaren artean (R. M. Pagola 1995):

\footnotetext{
${ }^{55}$ Cf. Corografía 299: "El dialecto navarro coincide mucho con el labortano, pero se diferencia también en muchas cosas".

${ }^{56}$ Vinsonek Larramendiren berriak bakarrik ezagutu zituen. Urquijok (ikus Arocena eta bien oharrak, loc. cit. 63-64. or.) Angel Irigarairen ale osatugabea (eta ezagun bakarra) izan zuen luzaro bere liburuen artean. Bertan "voy a poner aquí algunos datos acerca de mi ejemplar" idatzi baina egin gabe utzi zuen, tamalez.
} 
Larramendi

Cein concebitu baitzen Espiritu Santuaren obraz: Jaio cen Virgina Mariaren baitatic: pasatu zuen pasio dolorezcoa Poncio Pilato Juezaren azpian: Crucificatu izandu zen ill zen, ta orci zuten: Jautsi cen, etc.
Beriain

çeyn concebitu baytçen Espiritu Sanduaren obras, eta jayo-çen Virgina Mariaren baytatic: passatuçuen Passio doloroscoa, Poncio Pilato juezaren azpian crucificatu yçandu-çen yll-cen, eta orci-çuten: jautssi-cen...

Aldaketak:

- $<\mathrm{c}>\rightarrow<\mathrm{c}>$ edo $<\mathrm{z}>,<\mathrm{tç}>\rightarrow<\mathrm{tz}>$ : çeyn $>$ cein, baytçen $>$ baitzen, çen $>$ cen, çuen $>$ zuen, etab.

$-<\mathrm{y}>\rightarrow<\mathrm{i}>/ \mathrm{V}-\mathrm{C}, \#-$ Ceta $\mathrm{V}-\mathrm{V}$ : baytçen $>$ baitzen, baytatic $>$ baitatic, $y$ çandu $>$ izandu, yll $>$ ill, jayo $>$ jaio.

- Geminatuak bakundu: passatu > pasatu, jautssi $>$ jautsi.

- Txistukarien "zuzenketa": obras > obraz, doloroscoa $>$ dolorezcoa.

- Aditz nagusia eta laguntzailea bereiztea: jayo-çen > jaio cen, etab.

- Aldaera aldaketak: Sanduaren $>$ Santuaren, doloroscoa $>$ dolorezcoa, eta $>$ ta.

\section{Hegoaldeko dotrinak}

Dotrina multzo bat eskuartean izan zuela besterik ez dakigu: ${ }^{57}$

Fuera destos libros, se han impreso varios cathecismos, así en Bizcaya como en Guipúzcoa y Navarra; pero con poca atención a la pureza del bascuence y a su ortografía (Larramendi 1745: xxxv).

Dakusgunez, euren euskara baldresagatik aipamen labur hau baino gehiago zehaztetik atzeratu zen, baina honek ez du inondik inora esan nahi erabili ez zituenik, Landucciren kasuak erakusten digun bezala (Urgell 2001a: § 0.4.4). Frogatu egin behar, hortaz, baina Hegoaldekoak izanik, hain zuzen, filologoaren lana inoiz zailenik gertatzen da, hainbat kasutan hitzak irakurriak baino entzunak errazago izan baitaitezke, nabarmena denez.

Lehenengo arazoa, anitzen artean, multzoan zein sartzen ziren eta zein ez zehaztea dugu, eta nori ez zaizkio buruko ileak laztuko gaur izenez (Elso...) edo zatika bakarrik ezagutzen ditugun dotrinak ${ }^{58}$ edota, areago, ezagutzen ez dugunen bat Larramendik ezagut zitzakeela pentsatze hutsaz? Jakin gabean geratu gara, ordea, baita betirako

\footnotetext{
${ }^{57}$ Halaber, bere eskuz osatu zuen liburu zerrendan honako ohar ilun hau, hiztegikoaren parekoa, baino ez dugu aurkitzen: "Algunos librillos en bascuence y otros papeles sueltos" (Tellechea-Idigoras 1966a: 356, 80. zb.).

${ }^{58}$ Ik. TAV 3.2.10 (Zubiaren bizkaierazko eta Etxaberen gipuzkerazko Agur Maria-k), ib. 3.2.11 (1614ko Symbolum Apostolorum-eko Kredoa), ib. 3.2.12 (Isastiren Salvea), ib. 3.2.14 (Zubiaren Aita Gurea) eta ConTAV 5.2.8 (117-123. or., goi-nafarrerazko dotrina baten apurrak).
} 
geratu ere, eta, amets egitea bezain erakargarri ez bada ere, ausaz, ikerketaren argipean jar daitezkeen errealitate fisikoekin bakarrik jokatu behar dugu.

Aukeran ditugun liburuak ez dira asko, zortzi orotara: bizkaieraz ${ }^{59}$ Betolatza (1596), Viva Jesus (XVII. mendekoa), ${ }^{60}$ Kapanaga (1656), Arzadun (1731) eta Urkizu (1737); gipuzkeraz Otxoa de Arin (1713) eta Irazusta (1739); eta nafarreraz Elizalde (1735).

Esanak esan, begi-bistakoa dirudi ezen, oro har, zenbat eta berriago, hainbat eta Larramendik ezagutzeko aukera gehiago dagoela; bestela esanda, hiztegia prestatzen ari zen garaian erne ibili bide zenez gero, orduan argitaratutakoak ozta itzuriko zitzaizkion, guztiz 1734an Loiolara zenetik aurrerakoak. Ildo honetatik, ezin zaio halabeharrari egotzi, ezagutzen zituela zeharka jakin ahal izan dugun bakarrak hain zuzen 30 . hamarkadakoak izatea denak: Arzadun, Elizalde eta Irazusta. ${ }^{61}$

Ikerketaren une honetan, ziur xamar diren hiru iturrigai hauen aurkezpenera mugatuko naiz, nahiz $H H$-ko hitzekiko erkaketan aipatutako guztiak aintzat hartu ditudan, besteren bat ere multzoan sartu behar ote den egiaztatzeko. Dena dela, ezin esan gabe utzi, zeharkako iturriek azalarazi dituzten hiru dotrinekin Larramendik eman ezaugarri bakarra, alegia Bizkaia, Gipuzkoa eta Nafarroakoak zirela beteta dagoela, ziurrenik hirukote honi "varios catecismos" deitzea gehitxo den arren; gainera, bizkaieraz bederen gehiago ezagutu zituen, ezagutu ere, hiztegiaren hitzaurrean ("Del dialecto de Bizcaya” atalean, xxviii. or.) "...como se puede ver en algunos Cathecismos impressos deste dialecto" eta Corografia-n, hurren ikusiko dugun bezala, Arzadun bizkaierazko "zenbait dotrinaren" artetik adibidetzat jarriko duela baitio.

\footnotetext{
${ }^{59}$ Larramendik hartakotzat hartuko lituzkeenez ari naiz, noski: ezaguna da, bestalde, Betolatza azken urteotan Arabako euskararen lekukotzat hartu izan dela (Knörr 1986, Zuazo 1998c).

${ }^{60}$ Urtegabeko honen hizkuntzaz eman diren iritziak laburbilduta aurki daitezke Lakarra 1984: 176-177n.

${ }^{61}$ Larramendiren gelan (Altuna 1984: 81) Mikelestorenaren 1744ko argitalpen baten ale bat aurkitu zuen eskribauak, "de la Nobena del Corazón de Jesús". Guretzat ez bada ere (HH-rako ozta-ozta erabil zezakeen eta), bibliografoentzat bederen xehetasun interesgarria izan daiteke. Ezagutzen dugun idazle honen liburu bakarra Cerura nai duenac ar dezaquean vide erraza da, baina badu barruan "neuvaine au coeur de Jésus" bat, Vinsonek (1891-1898: 198-199, 82. zb.) zehaztu zuenez, eta agian honek eragin zuen Landaren izenburu delakoa. Vinsonek, ordea, 1751ko argitalpena bakarrik ezagutu zuen; Larramendirenaz gainera, bada bederen beste argitalpen bat, urte gabekoa baina itxuraz berriagoa, "Iruñean: Longas Echean" egina (Amezaga 1983: 109, 289. zb.); honen atal banaketa aldez ezberdina da: "Ongui vicitzeco modu labur errazac", 3-39; "Meza entzuteco modua", 39-64; "Calvarioco estacioac", 65-87; "Acto fedeco, esperantzaco eta Caridadecoac", 88-92; aipatu bederatziurrena ez da inon ageri.
} 


\subsection{Arzadun}

Bizkaiera ordezkatzeko aukeratu zuen:

No he visto libro ni tratado en este dialecto sino algunos catecismos. Pondré un ejemplar del que imprimió el año de 1731 don Martín de Arzadun, beneficiado y grave eclesiástico de Durango (Corografía 298).

Arzadunen Doctrina christianeen explicacinoa Gasteizen argitaratu zen lehenengoz

(Vinson 1891-1898: 166-167, 52. zb.), Larramendik aipatutako urtean, hain zuzen. Urquijok (1907b) erdietsi zuen gordetzen den ale bakarra, dakigularik. ${ }^{62}$ Hona Larramendiren transkripzioa 1731koarekin erkatuta:

\section{Larramendi}

Izanic christinauen señalea Curutze Santea, dalaco Christo Crucificaduen figurea, ceinetan erredimidu guinduzan bere odol preciobacoagaz, beardau jaquin eguiten señale au, ceñatuten dala da santiguetan dala ondo. Cer da Ceñatutea? Eguitea Iru Curutze escumaco escuco orcoroagaz, da urrengo atzagaz ifiniric Curutzez, beste iru atzac gueldietan direala artez. Nun eingo diraz iru curutzecoac, da cer verbagaz? Leleengoa becoqui ganeric sur puntara, da becoquien ezquerreco alderic escumacora, esaten dala: Curutze Santeen señaleagaiti: bigarrena sur puntaric ocotzera, da aoen ezquerreco alderic escumacora, esaten, dala, gueure arerioetaric libradu gaguizuz: da irugarrena ocotzeric bularrera, da ezquerreco solbardaric escumacora, esaten dala: gueure Jauna da Jaungoicoa. Cer da Santiguetea? Eguitea Curutze bat escumaco escuco bost atzacaz, ifinten direala artez. Nun eingo da Curutze au da ce verbagaz? Becoquiric bularrera, da ezquerreco solbardaric escumacora, esaten dala: becoquian, Aitien: bularrean, da Semien da ezquerreco solbardaric escumacora da Espiritu Santuen icenean.
Arzadun

Izanic christiauen señalea Curuce Santea, dalaco Christo Crucificaduen figurea, ceinetan erredimidu guinduzan bere odol preciobacoagaz, beardau jaquin eguiten señaleau, zeñatutendala da santiguetandala ondo. (...). Cerda zeñatutea? Eguitea Iru Curuze escumaco escuco orcoroagaz, da vrrengo azagaz ifiniric Curuzez, beste iru azac geldietan diriala artez. Nun eingodiraz iru curuceoc, da ce verbagaz? Leleengoa becoquiganeric sur puntara, da becoquien ezquerreco alderic escumacora, esatendala; Curuze Santeen señaleagaiti: bigarrena sur puntaric ococera, da ahoen ezquerreco alderic escumacora, esatendala, gueure arerioetaric libradugaguizuz: da irugarrena ococeric bularrera, da ezquerreco solbardaric escumacora, esatendala: gueure Jauna da Jaungoicoa. (...). Cer da Santiguetea? Eguitea Curuce bat escumaco escuco bost azacaz, ifintendiriala artez. Nun eingoda Curuce au da ce verbagaz? Becoquiric bularrera, da ezquerreco solbardaric escumacora, esatendala: becoquian, Aitien: bularrean, da Semien da ezquerreco solbardaric escumacora $d a$ Espiritu Santuen icenean.

\footnotetext{
${ }^{62}$ Berak erakutsi zuen bigarrena (Iruñean Martin Joseph de Radak egin 1758koa) hutsez eta aldaketez josita dagoela. Aldaketak, bestalde, oso interesgarriak dira, Lakarrak (1984: xvi-xviii) erakutsi bezala, batzuk Larramendiren iraultzaren ondoriotzat eman baitaitezke.
} 
Grafi aldaketa hutsek baino interes gehiago izan dezaketenak hauek dira:

- Txistukari afrikatuak frikarietatik bereiztea: curuce / curuze > curutze, azagaz > atzagaz, azac > atzac, ococera > ocotzera, etab.

- ia > ea: diriala > direala (bi bider).

- Aldaera aldaketak: ce $>$ cer.

\subsection{Elizalde}

Nafarreraren barneko ezberdintasunak agerian jartzeko, Beriainen aurkez aurke jarri zuen Larramendik:

Y el Padre Eleizalde en su doctrina del año 1735 pone ese mismo sentido así:... (Corografia 299).

Elizalderen Apezendaco dotrina christiana uscaras "Iruñan, Alfonso Burguete Alargunaren echean" atera zen, behin bakarrik, dakigularik (Vinson 1891-1898: 178, 57. zb.), Larramendik adierazi urtean, hain zuzen. Eskura dugu haren faksimilea (Salaberri Zaratiegi 1994). Larramendi eta Elizalderen bertsioak erkatuta:

\section{Larramendi}

Cein concebitu baice Espiritu Santuaren obraz: jaio ce Andre Maria Virginaren ganic: padecitu zue Poncio Pilatoren manuaren azpian: guretzificatu zute: il zute: jautsi ce, etc.

\section{Elizalde}

Cein concebitubaize Espiritu Sanduaren obras. Jayoce Andre Maria Virginaren ganic. Padecituzue Poncio Pilatoren manuaren azpian: gurucificatuzute, ilzute, orzizute: jausice...

Aldaketak:

- ze >ce: baize > baice.

- Txistukarien "zuzenketa": obras $>$ obraz, jausi $>$ jautsi.

- Aditz nagusia eta laguntzailea bereiztea: concebitubaize > concebitu baice, jayoce $>$ jaio ce, etab.

- Aldaera aldaketak: Sanduaren > Santuaren, gurucificatu > guretzificatu [sic].

\subsection{Irazusta}

Esan bezala, Irazustaren Doctrina christiana jasota agertzen da Landaren zerrendan (Altuna 1984: 77, 192. zb.; Iturriaga 1992: 170):

It. otra pregunta o cartilla de Doctrina Christiana en bascuence del Pe. Astete, traducida por Dn. Juan de Yrazusta. Impresa en Pamplona el año de 1759.

Ziurrenik, 1759ko data eskribauaren hutsa da, dakidalarik ez baitago urte horretako argitalpenik; lehena 1739koa izanik, gainera, ez dirudi 3 eta 5 nahastea zaila denik. 
Iturriagak dioenez (1992: 19), lehen argitalpena Loiolako Bibliotekan gordetzen da, ${ }^{63}$ hau Larramendiren hura balitz, bide batez, haren iturri izan ziren euskal liburuetatik Loiolan gordetzen den bakarra izango litzateke.

Ezagutzen den hurrengoa 1742koa da (Vinsonek lehenengotzat emana: ik. 18911898: 183, 62a zb.; Lakarra 1984: xxvii), baina XVIII. mendean hainbat bider berrargitaratua izan zen.

\section{Bibliografia}

Akesolo, Lino (arg.), 1970, Joannes Etcheberri. Noelak, Soc. Guip. de Ediciones y Publicaciones, Donostia.

—_——, (arg.), 1983, Bernard Gasteluçar. Eguiac [sic] catolicac, salvamendu eternalaren eguiteco necesario direnac, Euskaltzaindia, Bilbo.

Altuna, Patxi, 1984, "La auténtica biblioteca de Larramendi", Muga 228, 66-81.

Amezaga, Arantzazu, (zuz.), 1983, Eusko Legebiltzarra. Bibliografi Erroldea I, Arabako Foru Dip., Gasteiz.

Arcocha-Scarcia, Aurelie, 2003, "Manuscrits relatifs aux fables de la La Fontaine et de Florian traduites et adaptées du français au basque labourdin par Martin Goyhetche (1791-1859), Lapurdum 8.

—_, 2004, "Eguiatéguy, lecteur de Ioannes Etcheberri de Ciboure", Lapurdum 9.

Atutxa, Isaak, 1999, "Joannes Etcheberri Ziburukoa: Noelac eta testu kritika", Lapurdum IV, Numéro Spécial 1, 233-312. 21-60.

_———, 2002, "Joannes Etxeberriren Manual devotionezcoa-z", Lapurdum 7: 57-91.

Baum, Richard, 1989, Lengua culta, lengua literaria, lengua escrita, Alfa, Barcelona/Caracas.

Blecua, Alberto, 1991, "Los textos medievales castellanos y sus ediciones", Romance Philology, 45:1, 73-88.

Buzzetti, Carlo, 1986, La Biblia y sus transformaciones. Historia de las traducciones bíblicas y reflexiones hermenéuticas, A. Ortiz García, Ed. Verbo Divino, Estella.

Camino, Iñaki \& Lakarra, Joseba A., 1993, "Beriain osatuz", ASJU 27:3, 1029-1048.

ConTAV = Sarasola 1983.

Cremonesi, Carla, 1959, "Diccionario de la Lengua Castellana", in A. Viscardi, et alii, 1959, Le prefazioni ai primi grandi vocabolari delle lingue europee. I. Le lingue romanze, Instituto Editoriale Cisalpino, Milano/Varese, 325-354.

Dodgson, 1907, [oharra], Notes and Queries, 16. zb., martxoak 16.

\footnotetext{
${ }^{63}$ Eta ale honen kopia bat baliatu dut, hain zuzen, $\mathrm{HH}$-aren iturrien ikerketan.
} 
Gaskell, Philip, [1972], Nueva introducción a la bibliografía material, C. Fernández eta F. Alvarezen gazt. itzulp., Trea, Gijon, 1998.

$H H=$ Hiztegi Hirukoitza; ik. Larramendi 1745.

Iturriaga, Juan, 1992, Larramendi. Biblioteca del Santuario de Loyola. Catálogo e inventario de la Biblioteca personal del P. Manuel Larramendi, S.J, Universidad de Deusto, Bilbao.

Jones, William Jervis, 1991, "Lingua teutonum victrix? Landmarks in German lexicography”, HEL 13-2, 131-152.

Kerejeta, M. Jose, 1991, "Oihenart Silvain Pouvreauren hiztegian", ASJU 25:3, 865899.

Lacombe, Georges, 1907, "De quelques différences lexiques et typographiques entre des exemplaires du Nouveau Testament de Liçarrague", RIEV I, 180-182.

Lafon, R., [1944], Le système du verbe basque au XVI siècle. Berrarg. faks., Elkar, Donostia, 1980.

Lakarra, Joseba A., 1984, Euskal thesauruserako gaiak: Hegoaldeko testuak (17001745), EHUko tesina argitaragabea, Gasteiz.

————, 1985a, "Larramendiren hiztegigintzaren inguruan", ASJU XIX-1, 9-50.

———, 1985b, "Berriz Larramendiren segizioko zenbaitez", ASJU XIX-2, 439-452.

————, 1991, "Testukritika eta hiztegiak: Harriet eta Larramendi", in Lakarra \& Ruiz Arzalluz (arg.), I, 217-258.

- - - 1993, XVIII. mendeko hiztegigintzaren etorkiez. Doktorego tesi argitaragabea, EHU-Gasteiz.

———, 1994, "Harrieten Gramatikako hiztegiak (1741)", ASJU XXVIII-1, 1-178.

Larramendi, Manuel, 1729, El Imposible Vencido. Arte de la Lengua Bascongada, Salamanca. Arg. faksimilea, Hordago, Donostia, 1979.

_-_—, 1745, Diccionario Trilingüe del Castellano, Bascuence y Latín (2 lib.), San Sebastián. Arg. faksimilea, Txertoa, Donostia, 1984.

-_——, c. 1764, Corografía de Guipúzcoa, ms. de la Real Academia de la Historia, fondo Jesuitas, leg. 62. J. I. Tellechea Idigorasen arg., Sociedad Guipuzcoana de Ediciones y Publicaciones, Donostia, 1969.

Lázaro Carreter, Fernando, 1981, Estudios de Lingüística, Crítica, Barcelona.

Mayans, Gregorio, [1737], Orígenes de la Lengua Española, in Obras Completas II, Ayuntamiento de Oliva, Diputación de Valencia, 1984.

McKerrow, Ronald B., [1928²], Introducción a la bibliografía material. I. Moyanoren gazt. itzulp., Arco/Libros, Madril, 1998.

Mitxelena, Koldo, 1960, Historia de la literatura vasca. 2. arg., Erein, 1988. 361-372. , [1961], "Euskal iztegigilleak XVII-XVIIIgarren mendeetan". Orain SHLV I, , 1964, Textos Arcaicos Vascos, Minotauro, Madril.

, 1970, Estudio sobre las fuentes del Diccionario de Azkue, Centro de Estudios Históricos de Vizcaya, Bilbo. 
-——, et alii, 1987-2005, Orotariko Euskal Hiztegia / Diccionario General Vasco, Euskaltzaindia, etab., Bilbo, 16 lib.

Olaizola, Juan Maria de, 1993, Historia del Protestantismo en el País Vasco. El Reino de Navarra en la encrucijada de su historia, Pamiela, Iruña.

Pagola, Rosa Miren, 1995, "Beriainen dotrina”, Enseiucarrean 11, 15-69.

Quemada, Bernard., 1967, Les dictionnaires du français moderne (1539-1863). Etude sur leur histoire, leurs types et leurs méthodes, Didier, París, etab.

Ruiz Arzalluz, Iñigo, 1987, "Notas sobre algunas traducciones vascas del Nuevo Testamento", ASJU 21:3, 709-725.

-_—, 2003, Aitorkizunen historia eta testua. Orixeren eskuizkributik Lekuonaren ediziora, ASJU-ren gehigarriak 48, Donostia.

Salaberri Zaratiegi, Patxi, 1994, "Elizalderen Apecendaco dotrina christiana uscaras", FLV 26, 7-65.

Sarasola, Ibon, 1983, "Contribución al estudio y edición de textos antiguos vascos", ASJU 17, 69-212.

Schuchardt, H., [1900], "Prólogo" eta "Sobre el modo de disponer la reimpresión, en particular sobre las erratas y variantes en el texto de Leizarraga", I. Ruiz Arzallus eta J.M. Vélez Latorre-ren itzulpena, in Leizarraga 1571, 127-240.

Segurola, Koro, 2001, "Paperaren ur-markak", ASJU 35: 1, 215-240.

__——, 2002, "Jeanne d'Arc pastoralaren eskuizkribua: Le plus ancien connu?", Lapurdum 7, 313-326.

————, 2004, "XVIII. mendeko autore ezezagun bat", Lapurdum 9, 243-282.

$T A V=$ Mitxelena 1964.

Tellechea-Idigoras, Jose Ignacio, 1966a, "El jesuita Manuel de Larramendi”, BAP XXII, 307-360.

___ _ 1966b, "Nota autógrafa del P. Larramendi a la copia que hizo del Nuevo Testamento de Lizarraga. Advertencia", Colección de documentos inéditos para la Historia de Guipúzcoa 7, Publicaciones de la Excma. Diputación de Guipúzcoa, Donostia, 175-176.

Urgell, Blanca, 1991, “Axular eta Larramendi”, ASJU 25: 3, 901-928.

\section{3-685.}

1997, "Estudios en torno a la historia de la lexicografía vasca", ASJU 31:2,

, 1998, "Hiztegi Hirukoitza eta Diccionario de Autoridades erkatuaz (II): sarreraren edukia", ASJU 32:2, 365-414.

————, 2000a, Hiztegi Hirukoitza-ren osagaiez, tesi argitaragabea, EHU, Gasteiz.

____ 2000b, "Euskal edizioen historiaz", EHUaren Udako Ikastaroetan emandako hitzaldi argitaragabea. Bertsio elektronikoa artxiker-en kontsulta daiteke.

————, 2001a, "Larramendiren Eranskina: saio bat hiztegigintzaren testukritikaz", $A S J U$-ren gehigarriak 47, Donostia (kaleratzear).

107-183. 
—_——, 2002, "Hiztegi Hirukoitza-ren kanpoko eta barruko historiaz", in X. Artiagoitia, P. Goenaga \& J. A. Lakarra, Erramu boneta: Festschrift for Rudolf P. de Rijk, EHU, Bilbo, 629-649.

Urkizu, Patri, 1986, "Euskara XVI-XVII. mendeetako zenbait idazle atzerritarrengan”, ASJU 20:2, 343-350.

\section{Donostia.}

Villasante, Luis, (arg.), 1985, Lavieuxville-Harosteguy. Bayonaco Diocesaco bi-garren catichima, Euskaltzaindia, Bilbo.

Vinson, Julien, 1891-1898, Essai d'une Bibliographie de la Langue Basque. Berrarg. faks. J. Urquijoren oharrekin, ASJU-ren gehigarriak 9, Donostia, 1984. 287.

Zuazo, Koldo, 1998, "Betolatzaren hizkeraz”, in Knörr \& Zuazo (arg.), Arabako Euskararen Lekukoak. Ikerketak eta Testuak, Euskal Azterlan Bilduma 7, Eusko Legebiltzarra, 71-86.

Zulaika, Esther, 1999, Ioanes Leizarragaren aditza, Deustuko Unib., Donostia. 